Atmos. Chem. Phys., 20, 11697-11715, 2020

https://doi.org/10.5194/acp-20-11697-2020

(c) Author(s) 2020. This work is distributed under

the Creative Commons Attribution 4.0 License.

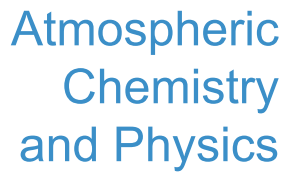

(c) (P)

\title{
Impact of the eruption of Mt Pinatubo on the chemical composition of the stratosphere
}

\author{
Markus Kilian, Sabine Brinkop, and Patrick Jöckel \\ Deutsches Zentrum für Luft- und Raumfahrt (DLR), Institut für Physik der Atmosphäre, Oberpfaffenhofen, Germany
}

Correspondence: Markus Kilian (markus.kilian@dlr.de)

Received: 17 February 2020 - Discussion started: 30 March 2020

Revised: 13 August 2020 - Accepted: 18 August 2020 - Published: 16 October 2020

\begin{abstract}
This article describes the volcanic effect of the Mt Pinatubo eruption in June 1991 on the ozone $\left(\mathrm{O}_{3}\right)$ and methane $\left(\mathrm{CH}_{4}\right)$ distribution in the stratosphere, as simulated with the chemistry-climate model EMAC (ECHAM/MESSy Atmospheric Chemistry: ECHAM5, version 5.3.02; MESSy, version 2.51). In this study, the effects of volcanic heating and heterogeneous chemistry on the chemical composition, caused by the volcanic aerosol, are separated. Global model simulations over the relevant period of the eruption from 1989 to 1997 with EMAC in T42L90MA resolution with specified dynamics and interactive chemistry were performed. The first simulation (VOL) contains the volcanic perturbation as an additional aerosol load and thus simulates the interaction of the aerosol with the chemistry and the radiation. The second simulation (NOVOL) neglects the eruption and represents the undisturbed atmosphere. In the third simulation (CVOL) the volcanic aerosol only interacts with the heterogeneous chemistry, such that volcanic heating is omitted. The differences between the simulation results VOL-NOVOL describe the total effect of the Mt Pinatubo eruption on the chemical composition, VOL-CVOL the stratospheric heating effect, and CVOL-NOVOL the chemical effect of the aerosol on the heterogeneous chemistry. The post-volcanic stratosphere shows a decrease in the $\mathrm{O}_{3}$ column in the tropics and an increase in the midlatitudes and polar regions, lasting roughly 1 year. This change in the ozone column is solely a result of the heating effect. The subsequent decrease in the ozone column is related to the chemical effect. The contribution of the catalytic loss cycles $\left(\mathrm{NO}_{x}\right.$, $\mathrm{HO}_{x}, \mathrm{ClO}_{x}$, and $\mathrm{BrO}_{x}$ ) on the depletion of $\mathrm{O}_{3}$ is analysed in detail. In the tropics, $\mathrm{CH}_{4}$ increases in the upper stratosphere because of stronger vertical transport.
\end{abstract}

\section{Introduction}

Major volcanic eruptions in the tropics are able to inject material into the stratosphere and perturb the physical and the chemical states of the climate system for several years and longer (Robock, 2000; Thomas et al., 2009; Muthers et al., 2015). The emissions are mainly ash and sulfur in the form of $\mathrm{SO}_{2}$, which oxidizes to sulfate in the stratosphere, and sulfate aerosols are formed within weeks. The Mt Pinatubo eruption in June 1991 decreased the tropical ozone column significantly, by 13-20 DU (Grant et al., 1992). Stratospheric ozone is a well-studied greenhouse gas with a great public interest because it absorbs UV radiation and protects human health from harmful radiation. The abundance of ozone is mainly controlled by the production via photolysis and depletion by catalysts such as $\mathrm{NO}_{x}, \mathrm{ClO}_{x}, \mathrm{BrO}_{x}$, and $\mathrm{HO}_{x}$ (Solomon, 1999). The yearlong ozone production in the tropics and the transport via the Brewer-Dobson circulation (BDC) towards the polar regions together with the ozone depletion due to the temperature-dependent PSCs (polar stratospheric clouds) and the resulting activation of chlorine explain the global distribution of $\mathrm{O}_{3}$.

The eruption of Mt Pinatubo on 12 June 1991 was one of the strongest volcanic eruptions in the 20th century (Thomas et al., 2009). It affected the chemical composition of the atmosphere considerably (Textor et al., 2004; von Glasow et al., 2009; Poberaj et al., 2011; Aquila et al., 2013). The sulfate aerosols formed were rapidly zonally dispersed and transported into both hemispheres by the BDC. They absorb the solar and the terrestrial infrared radiation, which results in a heating of the stratosphere and a cooling of the troposphere beneath (Labitzke and McCormick, 1992). Stenchikov et al. (1998) established that the near-infrared solar forcing mainly drives the stratospheric heating due to an 
increase in the atmospheric extinction by volcanic aerosol. Brühl et al. (2015) performed European Centre for MediumRange Weather Forecasts Hamburg - Modular Earth Submodel System (ECHAM/MESSy) Atmospheric Chemistry model (EMAC) simulations for the Pinatubo eruption to show the importance of radiative feedback on the dynamics. They stated that radiative heating by volcanic aerosols enhances tropical upwelling and accelerates the tape recorder. After the Mt Pinatubo eruption, the temperature in the lower and middle stratosphere increased by up to $3.5 \mathrm{~K}$ at $30 \mathrm{hPa}$ and decreased by $0.5 \mathrm{~K}$ in the troposphere (Labitzke and McCormick, 1992; Self et al., 1996; Robock, 2000; von Glasow et al., 2009). The volcanic heating by the Mt Pinatubo eruption led to an increase in the vertical ascent by $20 \%$ and the subsequent poleward transport of air from regions with low ozone and thus reduced the ozone column in the tropics (McCormick et al., 1995; Dameris et al., 2005). Moreover, volcanic heating modifies the ozone budget via an acceleration of the temperature-dependent reaction rates. Ozone measurements in the post-volcanic atmosphere of the Mt Pinatubo eruption showed a total ozone column decrease by $6 \%-8 \%$ in the tropics within a month after the eruption (Grant et al., 1992; Schoeberl et al., 1993; McCormick et al., 1995). McCormick et al. (1995) figured out that the bulk of the ozone loss after the Mt Pinatubo eruption appeared between 24 and $25 \mathrm{~km}$ with up to $20 \%$. The larger liquid aerosol surface accelerates the heterogeneous reactions and affects the $\mathrm{O}_{3}$ chemistry, e.g. converting $\mathrm{NO}_{x}$ into $\mathrm{HNO}_{3}$, provides and activates chlorine from reservoirs, and alters catalytic ozone destruction (Solomon et al., 1996; Solomon, 1999; Robock, 2000; Poberaj et al., 2011; Aquila et al., 2013).

Modelling studies on the eruption of Mt Pinatubo aim to understand which processes are responsible for the ozone changes and how these changes affect the dynamics. These studies differ with respect to the methodology. Rozanov et al. (2002) simulated the volcanically induced ozone depletion using a global circulation model (GCM) including interactive chemistry and stratosphere-troposphere interactions. Two ensembles of free-running model simulations were performed. One ensemble simulates the volcanic aerosol, hence including both the chemical and dynamical effects, and the second set uses no volcanic forcing. Likewise, a set of freerunning model simulations but with a coupled atmosphereocean-chemistry model has been used by Muthers et al. (2015). They were also interested in the role of different climate settings (specific atmospheric composition of greenhouse gases) and performed corresponding sensitivity studies.

Aquila et al. (2013) used ensembles of 10 free-running model simulations representing either the case of full interaction of volcanic aerosol with chemistry and radiation, with chemistry only, and with radiation only and one simulation without the eruption effect. They could attribute the change in ozone to dynamical and chemical effects in the post-Pinatubo period. Telford et al. (2009) combined two nudged simulations and one free-running simulation in order to distinguish between chemical and dynamical effects on ozone of the Mt Pinatubo eruption. Their first simulation nudged towards ERA-40 uses all aspects of the model with prescribed volcanic aerosol. The second nudged simulation is performed without Pinatubo but with an unperturbed background aerosol. The difference between both lead to the so-called chemical effect on ozone. Admittedly, the chemical effect of Telford et al. (2009) is not purely chemical because it still consists of both a volcanic heating with subsequent influence on the stratospheric dynamics and a perturbation of the heterogeneous chemistry. In our study, we separate the so-called chemical effect as described in Telford et al. (2009) into the heating effect, via absorption by the volcanic aerosol, and the pure chemical effect, through a change in the heterogeneous chemistry due to the aerosol surface. In our study the Telford et al. (2009) chemical effect is called the combined effect. The separation of both allows a better understanding and quantification of the detailed chemical processes concerning ozone. The new findings can be used to optimize the representation of volcanic eruptions in chemistryclimate models. Muthers et al. (2015) also simulated the temperature-driven effects decoupled from the chemical effect with a coupled atmosphere-ocean-chemistry-climate model but did not separate the chemical effect of the heterogeneous chemistry from the heating effect of the volcanic heating.

Here, we performed global simulations of the eruption from 1989 to 1997 with specified dynamics and full chemistry with the chemistry-climate model EMAC. One simulation contains the volcanic perturbation as an additional aerosol load (VOL) and thus the full interaction of the aerosol with the chemistry and the radiation. In the second simulation, only the chemistry on the volcanic aerosols is accounted for (NOVOL), and the third simulation neglects the eruption entirely and represents the undisturbed atmosphere (CVOL). The differences in the simulation results (VOL-NOVOL) describe the combined effect of the Mt Pinatubo eruption. VOL-CVOL displays the stratospheric heating effect and subsequent changes in transport. CVOL-NOVOL shows the pure chemical effect due to heterogeneous reactions on the volcanic aerosol and the modification of the relevant chemical cycles. Section 2 describes the chemistry-climate model EMAC, the set-up of the simulations, and the methodology of the analysis. Section 3 evaluates the simulation results with the Stratospheric Water and OzOne Satellite Homogenized (SWOOSH) and Total Ozone Mapping Spectrometer (TOMS) satellite data sets. In Sect. 4 the simulation results are presented. Section 5 discusses the findings and provides an outlook on further studies. Section 6 summarizes the most important results. This is a follow-up study of Löffler et al. (2016), who analysed the perturbation of the stratospheric water vapour by the Mt Pinatubo eruption. 




Figure 1. Colours show the monthly averaged liquid aerosol surface area density $\left(10^{-8} \mathrm{~cm}^{2} \mathrm{~cm}^{-3}\right)$ of the volcanic sulfate aerosols in simulations VOL and CVOL in the stratosphere as tropical averaged vertical time series between $20^{\circ} \mathrm{S}$ and $20^{\circ} \mathrm{N}$ (a) and as latitudinal time series at $20 \mathrm{hPa}$ (b). The intervals of the colour scale are not equidistant.

\section{Model simulations}

\subsection{Model description}

The European Centre for Medium-Range Weather Forecasts Hamburg - Modular Earth Submodel System (ECHAM/MESSy) Atmospheric Chemistry model (EMAC) is a numerical chemistry and climate simulation system that includes sub-models describing tropospheric and middleatmosphere processes and their interaction with oceans, land, and human influences (Jöckel et al., 2010, 2016). It uses the second version of MESSy to link multi-institutional computer codes. The core atmospheric model is the fifth generation European Centre Hamburg general circulation model ECHAM (Roeckner et al., 2006). For the present study we applied EMAC (ECHAM5 version 5.3.02, MESSy version $2.51)$ in the T42L90MA resolution, i.e. with a spherical truncation of T42 (corresponding to a quadratic Gaussian grid of ca. $2.8^{\circ} \times 2.8^{\circ}$ in latitude and longitude) with 90 vertical hybrid pressure levels up to $0.01 \mathrm{hPa}$.

The forcing of the volcano in the model is represented by the prescribed surface area density in time and space (Figs. 1 and 2). Hence, volcanic aerosols in the simulations VOL and CVOL are not treated by an interactive aerosol module, but the volcanic aerosols are based on measurements from satellites. This means that the aerosol interacts with clouds and radiation but does not consider the impact of the atmospheric dynamics on the aerosol distribution. The aerosol data originate from the Chemistry-Climate Model Initiative (CCMI) data set, which is based on different satellite measurements (Diallo et al., 2017; Revell et al., 2017): Stratospheric Aerosol Measurement (SAM), Stratospheric Aerosol and Gas Experiment (SAGE I and II), Cloud Aerosol Lidar and Infrared Pathfinder Satellite Observations (CALIPSO), and Optical Spectrograph and InfraRed Imaging System (OSIRIS). It describes a single-mode log-normal aerosol size distribution derived by means of the SAGE- $4 \lambda$ algorithm, which is compiled from four wavelengths (385, 452,525 , and $1024 \mathrm{~nm}$ ) of SAGE II data when available (Revell et al., 2017).

\subsection{ESCiMo consortial simulations}

The volcanic simulations of this study were performed like multiple simulations with different boundary conditions within the Earth System Chemistry integrated Modelling (ESCiMo) project (Jöckel et al., 2016). These model simulations were defined to improve the understanding of processes in the atmosphere and also to help answer questions related to climate change, ozone depletion, and air quality, which is an important contribution to the WMO/UNEP (World Meteorological Organization/United Nations Environment Programme) ozone and IPCC (Intergovernmental Panel on Climate Change) climate assessments (WMO, 2019).

Here we employ these simulations and assess the impacts of the Mt Pinatubo eruption on the atmospheric chemistry. In our study we focus on three simulations with specified dynamics. They are branched off from a specified-dynamics hindcast simulation and are "nudged" with a Newtonian relaxation technique towards 6-hourly ERA-Interim reanalysis data from the ECMWF (European Centre for MediumRange Weather Forecasts), which has been available since 1979. The Newtonian relaxation (nudging) is applied to the prognostic variables divergence, vorticity, temperature, and the (logarithm of the) surface pressure in spectral space with relaxation times $\tau_{x}$ of $48,6,24$, and $24 \mathrm{~h}$, respectively. The global-mean temperature $(\bar{T})$ is not affected by the nudging technique because we exclude nudging of the "wave0 " in spectral space. Moreover, the nudging is not applied uniformly in the vertical: the boundary layer and the stratosphere above $10 \mathrm{hPa}$ are not nudged. The simulations VOL, CVOL, and NOVOL span the years 1989 to 1997.

The set-up (Table 1) is comparable to those of the EMAC simulations from Löffler et al. (2016), who simulated the effect of volcanic heating on SWV (stratospheric water vapour). In our study, VOL considers the volcanic aerosols and its interaction with both the radiation and the chemistry and shows the combined effect of the volcanic eruption. NOVOL omits the volcanic eruption by using an annual 

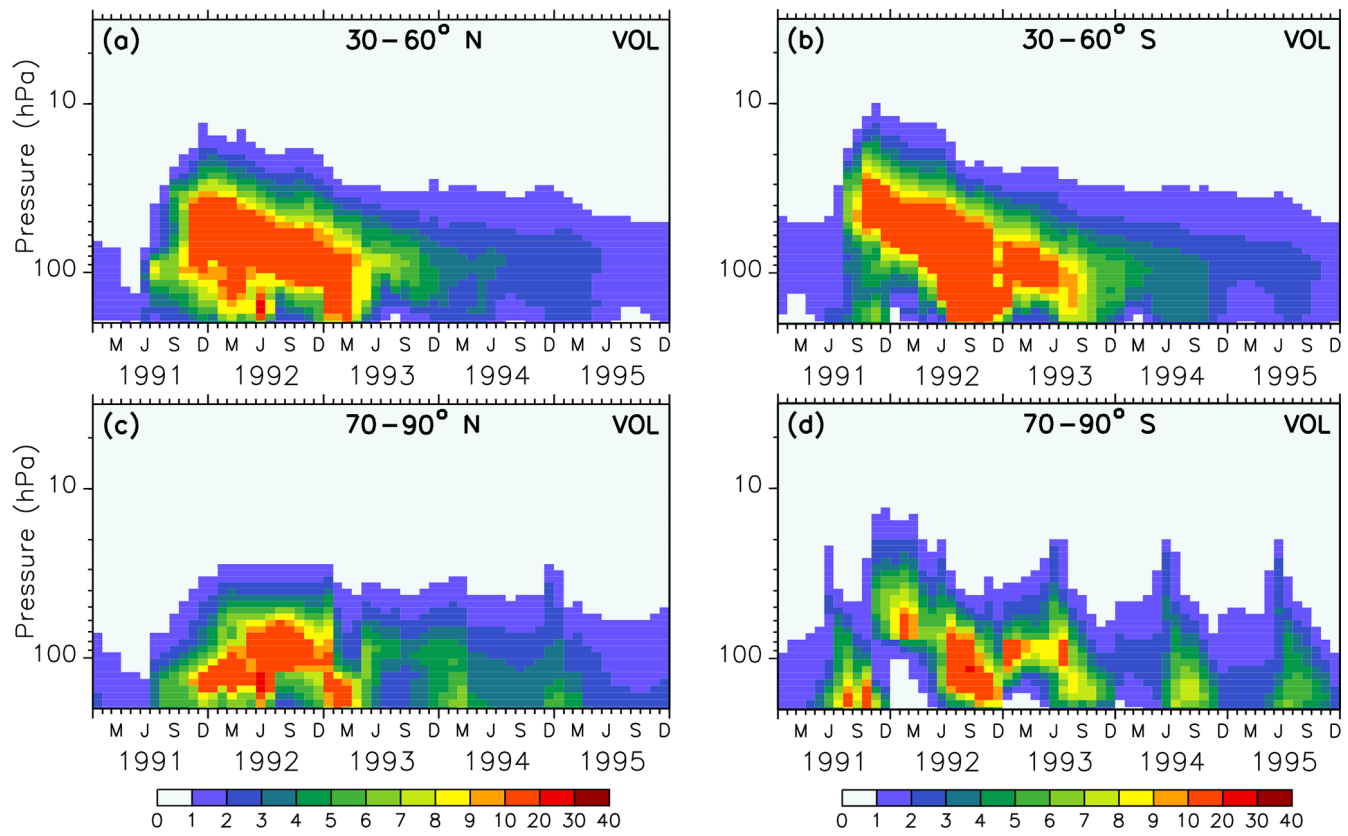

Figure 2. Colours show the monthly averaged liquid aerosol surface area density $\left(10^{-8} \mathrm{~cm}^{2} \mathrm{~cm}^{-3}\right)$ of the volcanic sulfate aerosols used as boundary conditions in simulations VOL and CVOL in the stratosphere as averaged vertical time series in the midlatitudes (a, b) and in the polar regions $(\mathbf{c}, \mathbf{d})$. The intervals of the colour scale are not equidistant.

Table 1. Overview of the three simulations with their differences in model set-up.

\begin{tabular}{lcl}
\hline Simulation & Volcanic aerosol & Aerosol interaction \\
\hline VOL & $\mathrm{x}$ & Radiation, chemistry \\
CVOL & $\mathrm{x}$ & Chemistry \\
NOVOL & - & - \\
\hline
\end{tabular}

background aerosol from the year 2011 that is almost unperturbed. Years without any volcanic eruptions are rare, but the background aerosol we used is only marginally affected by the mid-size volcanic eruption of Nabro in 2011. Despite this, sulfate aerosols of the eruption of Nabro, measured by the Michelson Interferometer for Passive Atmospheric Sounding (MIPAS), reached altitudes of up to $18 \mathrm{~km}$ (Griessbach et al., 2016). CVOL considers the volcanic aerosols like VOL, but only the heterogeneous reactions on the aerosol surface are affected, whereas the radiative transmission remains unaffected by the volcanic aerosols.

\subsection{Methodology}

The results are presented as differences of monthly mean values between the simulations, with exceptions being denoted clearly. The goal is to separate the heating effect of volcanic aerosols from the chemical effect caused by the altered heterogeneous chemistry on the ozone distribution. The difference VOL-NOVOL shows the combined effect of the stratospheric temperature increase due to absorption by volcanic aerosols and the intensification of the heterogeneous reactions, due to an increase in the aerosol surface density. VOL-CVOL yields the stratospheric heating effect, which includes the absorption of solar radiation by the volcanic aerosol and changes in transport as well as the secondary change in the temperature-dependent heterogeneous reaction rates. The pure chemical effect induced by the larger aerosol surface can be separated by the difference of CVOL-NOVOL. Due to the applied nudging, the temporal evolution of the synoptic conditions is similar in all three simulations. Using nudged simulations has several advantages over free-running simulations to study the impact on the chemistry: first, the temperature response is closer to observations, which is important, as ozone chemistry is temperature dependent, and second the results appear less noisy. Our (nudged) simulation pair (VOL and NOVOL) is similar with respect to the synoptic situation, so the effect of aerosol heating on subgrid-scale chemistry and the transport of ozone can be revealed more clearly. This would be more difficult if one allowed the synoptic situation to evolve freely. Moreover, for such a concept a large set of ensemble simulations is necessary (Aquila et al., 2013). In order to show how strongly the stratospheric temperatures in VOL and CVOL are perturbed by nudging, Löffler et al. (2016) (their Supplement, Fig. S2) performed two quasi free-running simulations (named QF), one with volcanic aerosol heating and one without. In the QF simulation pair only the (logarithm) of the surface pressure is nudged (and SST (sea surface temperature) and SIC (sea ice 
concentration) are prescribed) to study the effect of omitting the nudging of temperature, divergence, and vorticity on the results. The temperature difference of the QF simulation pair is larger compared to that of the nudged pair (about $50 \%$; Figs. S1 and S2 of Löffler et al., 2016) and, moreover, appears noisy. As already stated by Löffler et al. (2016), nudging (of temperature, divergence, and vorticity) reduces the cold-point temperature during the eruption. However, the development of temperature is similar to the nudged simulation pairs. The one-by-one comparison shows the volcanic perturbations and only a sub-synoptic noise because the effects of nudging cancel out. The production and loss rates of ozone are calculated off-line with the diagnostic tool STratO3Bud as described by Meul et al. (2014) and Grewe et al. (2017).

\section{Comparison with observations}

The EMAC model has been evaluated intensively by Jöckel et al. $(2006,2010,2016)$ and, with a focus on the Arctic polar stratosphere, by Khosrawi et al. $(2017,2018)$. In order to show the reliability of the simulated ozone distribution here, the volcanic simulation VOL is compared with the SWOOSH data set provided by NOAA (National Centers for Environmental Information; Davis et al., 2016), and the TOMS data set processed by the Goddard Space Flight Center's Ozone Processing Team arising from satellite observations (TOMS-Science-Team, 2004; Wellemeyer et al., 2004). The SWOOSH data set was constructed to investigate the variability and change in water vapour and ozone in the stratosphere. SWOOSH is a database of global long-term satellite $\mathrm{O}_{3}$ and SWV measurements presented on a vertical grid as monthly averages on pressure levels. The measurements from different satellite instruments, namely SAGE II, SAGE III, the Halogen Occultation Experiment (HALOE) on the Upper Atmosphere Research Satellite (UARS), and the Microwave Limb Sounder (MLS) on Aura as well as from other merged data products have been combined. The TOMS data set was constructed to investigate the distribution of the total ozone column under extreme conditions like during a strong aerosol load (Wellemeyer et al., 2004). The spatial and temporal distribution of ozone in VOL corresponds to the SWOOSH data (Fig. 3). The ozone layer between 5 and $20 \mathrm{hPa}$ with mixing ratios of $10-12 \mathrm{ppmv}$, as well as the seasonal cycle, are well represented. With the Mt Pinatubo eruption in June 1991, the atmosphere was too opaque for reliable satellite measurements, and consequently, those months are marked with white stripes showing the data gap. Figure 4 shows the comparison of the total ozone column between simulations VOL and the TOMS data. The annual maxima of the total ozone column in VOL in the northern and southern midlatitudes (Fig. 4a, b) is systematically overestimated by more than $20 \mathrm{DU}$ in comparison to the TOMS observations. This is consistent with the evaluation of the total ozone column of the nudged ESCiMo simulations with the BSTCO
(Bodeker Scientific combined total column ozone database) observations by Jöckel et al. (2016), who also found an overestimation of total ozone in the northern and southern midlatitudes of up to 10-20 DU (Jöckel et al., 2016, Fig. 27h). During the period of transition to the ozone minimum in the southern spring the difference decreases down to $5 \mathrm{DU}$. At the Antarctic polar cap the total ozone column simulated in VOL compares well with the TOMS data (Fig. 4d). The ozone maxima at the North Pole during spring are overestimated more strongly (up to $40 \mathrm{DU}$ ) by the VOL simulation than at the South Pole (10-15 DU, Fig. 4b, d). The seasonal ozone cycle in VOL corresponds well to the TOMS data in both hemispheres.

\section{Results}

In the Results section, we show the effect of the volcanic perturbation on temperature, on the vertical ozone column, on the vertical distribution of ozone, the chemical cycles, and the PSCs. First, we investigate the temperature perturbation because sulfate aerosols in the stratosphere increase the atmospheric extinction, resulting in a higher absorption of terrestrial (longwave) and solar (shortwave) radiation warming the stratosphere. Heterogeneous ozone chemistry is affected by the sulfate aerosols, which alter the ozone depletion cycles. Temperature changes at the tropopause perturb the cold point and alter the transport of SWV. An increase in the vertical transport also modifies methane. Since the ozone chemistry in the polar regions is strongly affected by the formation of PSCs, their behaviour in a post-volcanic stratosphere is analysed.

\subsection{Temperature}

The strongest heating due to absorption of solar and terrestrial infrared radiation by volcanic aerosols and by the increase in ozone due to transport occurs in the middle stratosphere of the tropics (Fig. 5b). Figure 5c shows the indirect volcanic heating by the perturbed heterogeneous chemistry, which changes the chemical composition of ozone and causes additional absorption. The combined effect (Fig. 5a), which is defined as the sum of the transport and the chemical effect, shows the strongest heating in the lower and middle stratosphere in December 1991. The vertical extent is congruent with the volcanic aerosol plume. The largest temperature increase occurs between 40 and $60 \mathrm{hPa}$ in the tropical stratosphere. In Fig. 5b (VOL-CVOL) the strongest heating occurs at the same height, but it is stronger with a maximum between $40^{\circ} \mathrm{N}$ and $40^{\circ} \mathrm{S}$. Figure $5 \mathrm{c}$ displays a heating of up to $0.4 \mathrm{~K}$ in the upper stratosphere between 5 and $20 \mathrm{hPa}$ and a cooling of up to $0.2 \mathrm{~K}$ between 30 and $70 \mathrm{hPa}$. More stratospheric ozone increases temperature due to more absorption of solar radiation, and less ozone cools the stratosphere. Thus, the main temperature change in this volcanic erup- 


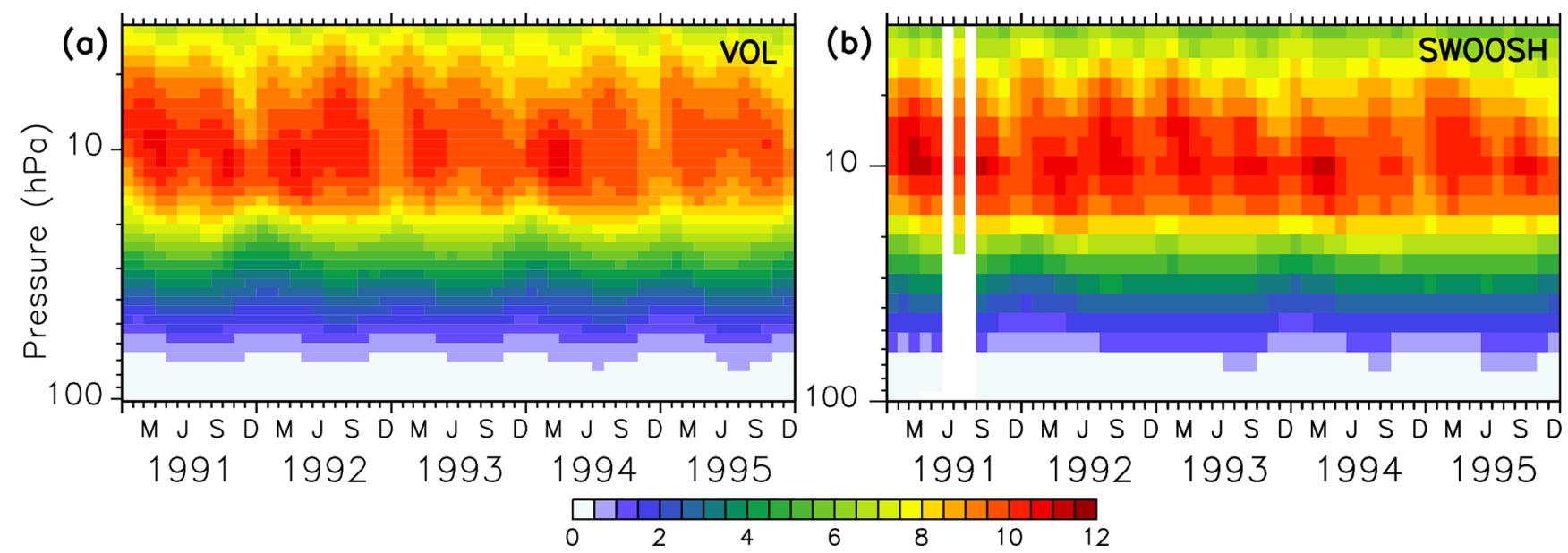

Figure 3. Colours show the absolute zonally and monthly averaged ozone mixing ratios (ppmv) at $10^{\circ} \mathrm{N}$ of the volcanic simulation VOL (a) and the SWOOSH satellite data set (b) for the period from 1991 to 1995 (Davis et al., 2016).
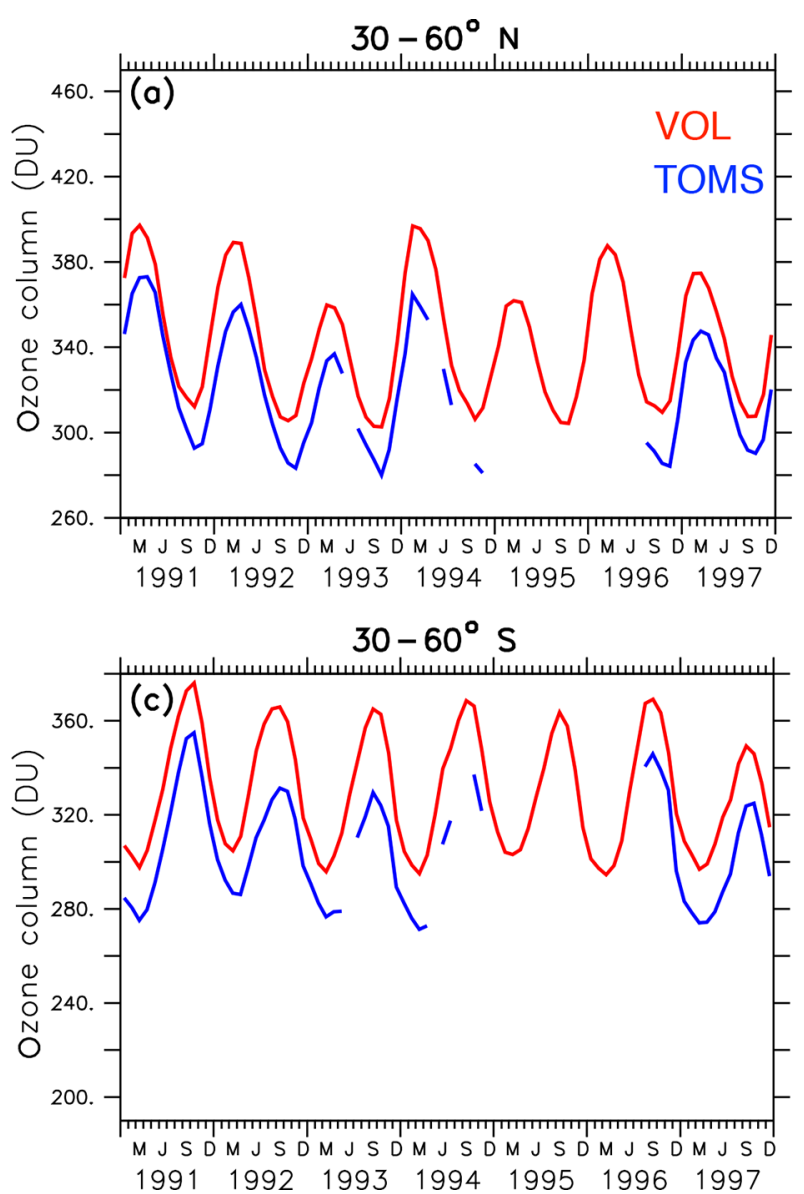
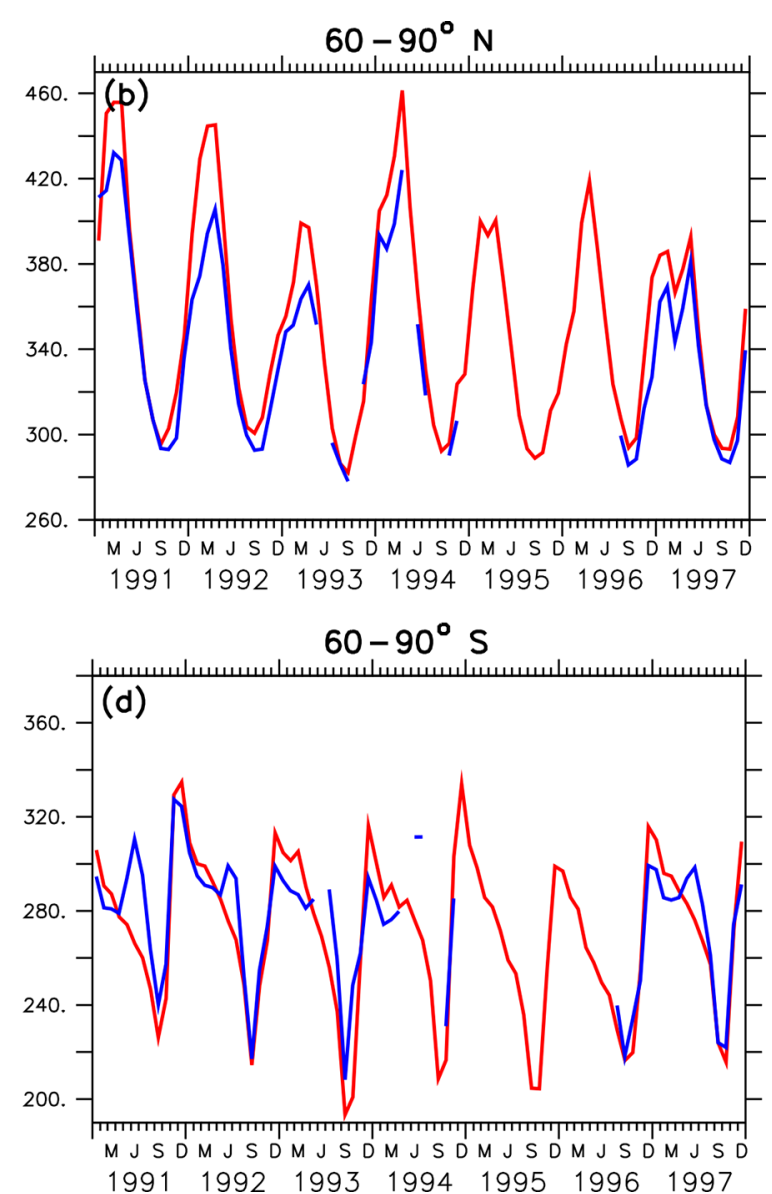

Figure 4. Lines show the zonally and monthly averaged total ozone column (DU) between $30-60^{\circ} \mathrm{N}$ (a) and 60-90 $\mathrm{N}(\mathbf{b})$ as well as between $30-60^{\circ} \mathrm{S}(\mathbf{c})$ and $60-90^{\circ} \mathrm{S}$ (d) of the volcanic simulation VOL and the TOMS data for the period from 1991 to 1997 (TOMS-Science-Team, 2004). The period between 1994 and 1996 shows data gaps because the atmosphere was too opaque for reliable ozone measurements. 

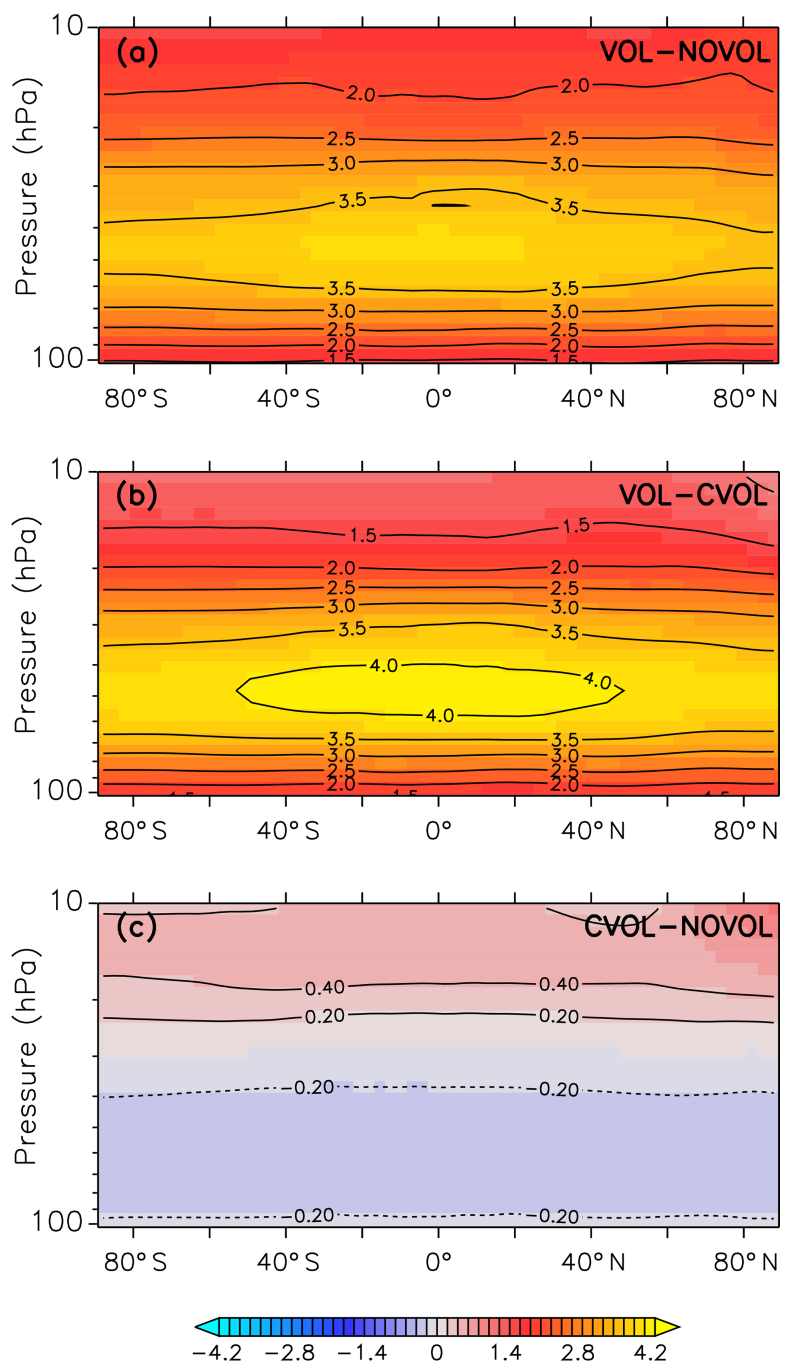

Figure 5. Monthly mean of the zonally averaged stratospheric temperature difference $(\mathrm{K})$ between the model simulations (CVOL and NOVOL) for December 1991. Panel (a) shows the combined effect, (b) the heating effect, and (c) the chemical effect. Black contours indicate the isothermal curves $(\mathrm{K})$. Contour intervals are $0.5 \mathrm{~K}$ in $(\mathbf{a}, \mathbf{b})$, and $0.2 \mathrm{~K}$ in $(\mathbf{c})$.

tion arises mostly from radiative absorption by the volcanic aerosol superimposed by a cooling due to reduced ozone.

\subsection{Total ozone column}

Our simulations show that the total ozone column decreases in the first 12 months after the eruption of Mt Pinatubo by up to $18 \mathrm{DU}(6 \%)$ in the tropics (Fig. 6a). In contrast, the midlatitudes and the polar regions experience an increase in the total ozone column by $8-12 \mathrm{DU}(2 \%)$, smaller in the southern than in the northern midlatitudes. In May 1992, an ozone reduction propagates towards the North Pole, and in August 1992 a similar anomaly propagates towards the South Pole. The combined effect (Fig. 6a) is the sum
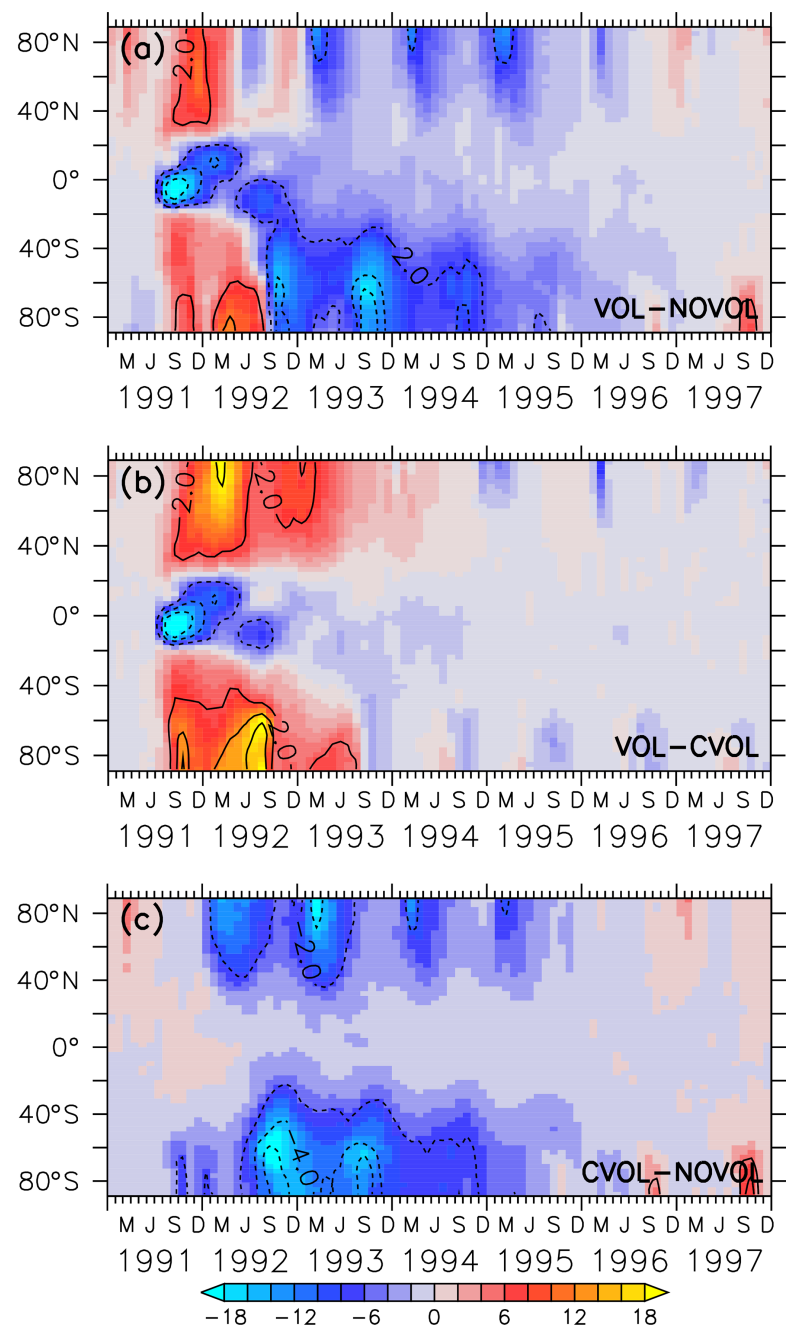

Figure 6. Colours show the differences in the zonal mean total ozone column (DU) as combined effect (VOL-NOVOL) (a), heating effect (VOL-CVOL) (b), and chemical effect (CVOL-NOVOL) (c) as a function of the latitude in degrees $\left({ }^{\circ}\right)$. Contours indicate the corresponding relative changes $(\%)$. Contour intervals are $2 \%$.

$(\mathrm{VOL}-\mathrm{CVOL})+(\mathrm{CVOL}-\mathrm{NOVOL})=\mathrm{VOL}-\mathrm{NOVOL}$ of the heating (Fig. 6b) and chemical effect (Fig. 6c); thus the change in the total ozone column is caused by a superposition of both effects (Fig. 6b, c). The decrease in ozone in the tropics and the increase in the midlatitudes and higher latitudes in the first 2 years after the Mt Pinatubo eruption are caused solely by the volcanic heating (Fig. 6b), i.e. the increase in the BDC through the volcanic aerosol-induced heating of the stratosphere and a subsequent increase in the transport of ozone. This result is in contradiction to Poberaj et al. (2011), who attributed the absence of ozone depletion in the Southern Hemisphere to interannual dynamic variability.

The ozone decrease by up to $4 \%$ in the North Pole region and by up to $6 \%$ in the South Pole region, starting in the re- 

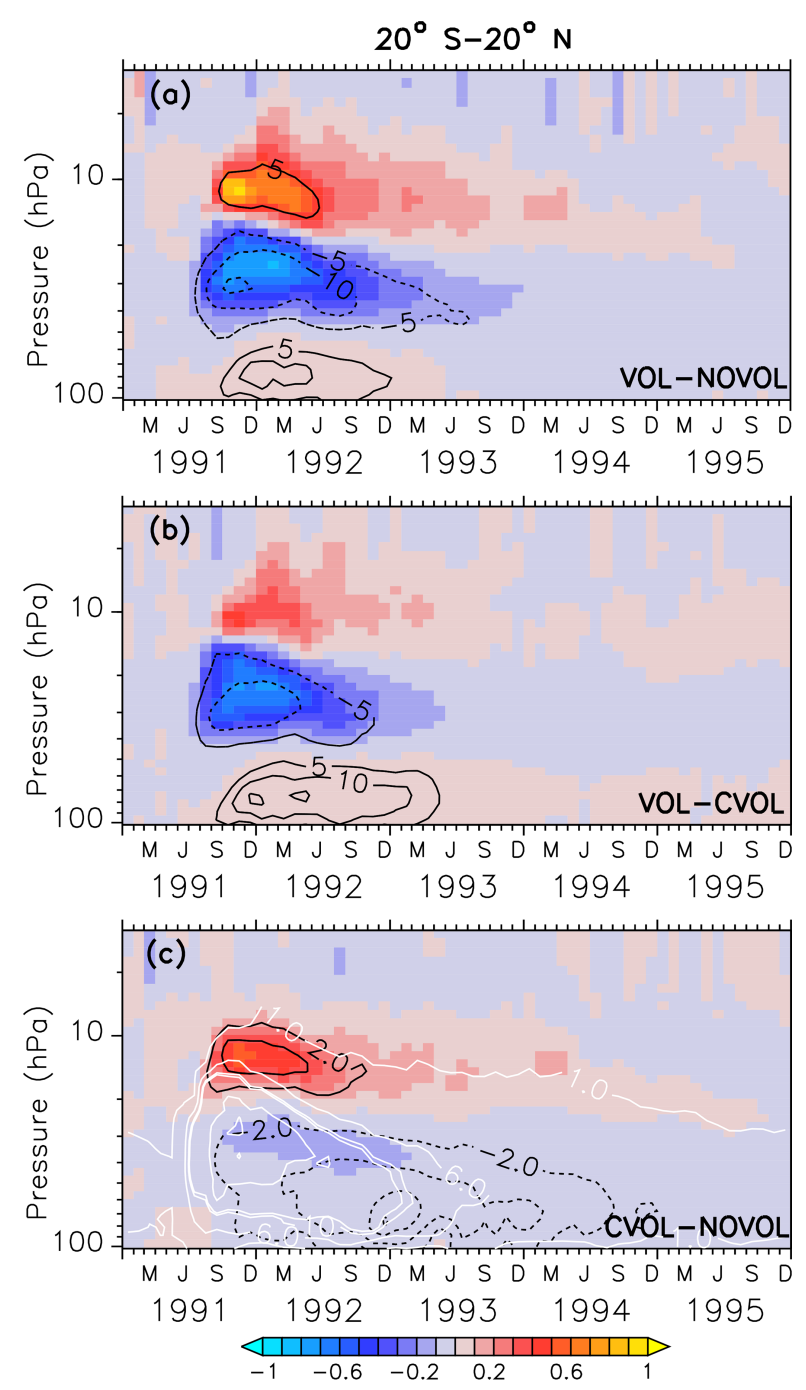

Figure 7. Zonally averaged differences in ozone mixing ratios (ppmv) between two simulation results, where (a) shows the combined effect (VOL-NOVOL), (b) the heating effect (VOL-CVOL), and (c) the chemical effect CVOL-NOVOL). Black contours indicate the corresponding relative changes (\%). Shown are averages in the tropics between $20^{\circ} \mathrm{S}$ and $20^{\circ} \mathrm{N}$. Contour intervals are $5 \%$ in $(\mathbf{a}, \mathbf{b})$ and $2 \%$ in (c). White contours in (c) show the liquid aerosol surface area density $\left(10^{-8} \mathrm{~cm}^{2} \mathrm{~cm}^{-3}\right)$ in VOL and CVOL with intervals of 1, 5, and 10.

spective spring seasons of 1992 , is due to the chemical effect alone (Fig. 6c).

Thus, the heating and chemical effect alter the ozone distribution in the midlatitudes and in the polar regions in opposite directions. Overall, the volcanic perturbation of the total ozone column lasts until the end of 1995. Some small artefacts at the poles in 1996 and 1997 arise from the background aerosol distribution used in the NOVOL simulation (see Sect. 2.2).

\subsection{Vertical ozone distribution}

The combined effect on ozone in the tropics is characterized by an increase of $5 \%$ around $10 \mathrm{hPa}$ and by a decrease of $15 \%$ between 20 and $50 \mathrm{hPa}$ (Fig. 7a). This dipole structure appears in both the heating (VOL-CVOL) and the chemical effect (CVOL-NOVOL), and they sum up to the combined effect (VOL-NOVOL; Kilian, 2018). The largest impact in the middle stratosphere is mostly attributed to the volcanic heating (Fig. 7b). The perturbation of ozone lasts for about 2 years. Volcanic heating by the aerosol modifies ozone via an increase in the vertical ascent by $20 \%$ and subsequent transport to higher latitudes, which reduces the tropical ozone column (McCormick et al., 1995; Dameris et al., 2005). The ozone increase at $10 \mathrm{hPa}$ arises partly from the chemical effect (Fig. 7c). As will be more precisely explained in Sect. 4.4, a larger liquid aerosol surface modifies the heterogeneous reactions and $\mathrm{NO}_{x}$ is converted into $\mathrm{HNO}_{3}$. Thus, less $\mathrm{NO}_{x}$ is available and the catalytic ozone depletion via $\mathrm{NO}_{x}$ slows down. In accordance with Telford et al. (2009), the chemical ozone decrease in the tropics is smaller than the dynamical effect, due to increased vertical transport (or heating effect).

In the extratropics, the combined $\mathrm{O}_{3}$ perturbation also exhibits a dipole structure with an increase in $\mathrm{O}_{3}$ between 10 and $30 \mathrm{hPa}$ by up to $5 \%$ and a small decrease in ozone below, which lasts for more than 1 year (Fig. 8a). This increase mostly arises from the chemical effect. Again, the $\mathrm{NO}_{x}$ cycle slows down so that less $\mathrm{O}_{3}$ is depleted (see Sect. 4.4). Interestingly, the heating effect and the chemical effect have counteracting influences on the ozone mixing ratio in the lower stratosphere, with an increase due to the volcanic heating, and a decrease in the same order of magnitude by the chemical effect (Fig. 8b, c). A similar dipole pattern is also observed in the polar regions, where the perturbation of ozone is even larger than in the extratropics (Fig. 9). Similarly, the heating and chemical changes are counteracting each other with up to $\pm 10 \%$ at the North (Fig. 9b, c) and up to $\pm 20 \%$ at the South Pole (Fig. 9e, f), mostly between 100 and $300 \mathrm{hPa}$. In the polar regions the seasonal cycle of the ozone perturbation is large and enhanced by the formation of PSCs (Sect. 4.4.1), so that the strongest effect appears during the respective spring season. The ozone decrease due to the chemical effect between 100 and $300 \mathrm{hPa}$ lasts for 4 years, whereas the ozone increase by the heating effect in the lower and middle stratosphere already disappears after 1 year. The next section describes whether the chemical effect on ozone arises from a perturbation of the ozone production or the ozone loss and how the net ozone production is affected.

\subsection{Ozone budget of the chemical effect}

In the following, we analyse the chemical effect (CVOL-NOVOL) on the $\mathrm{O}_{3}$ budget for the tropics, the midlatitudes, and the polar regions (Figs. 10-12). All 

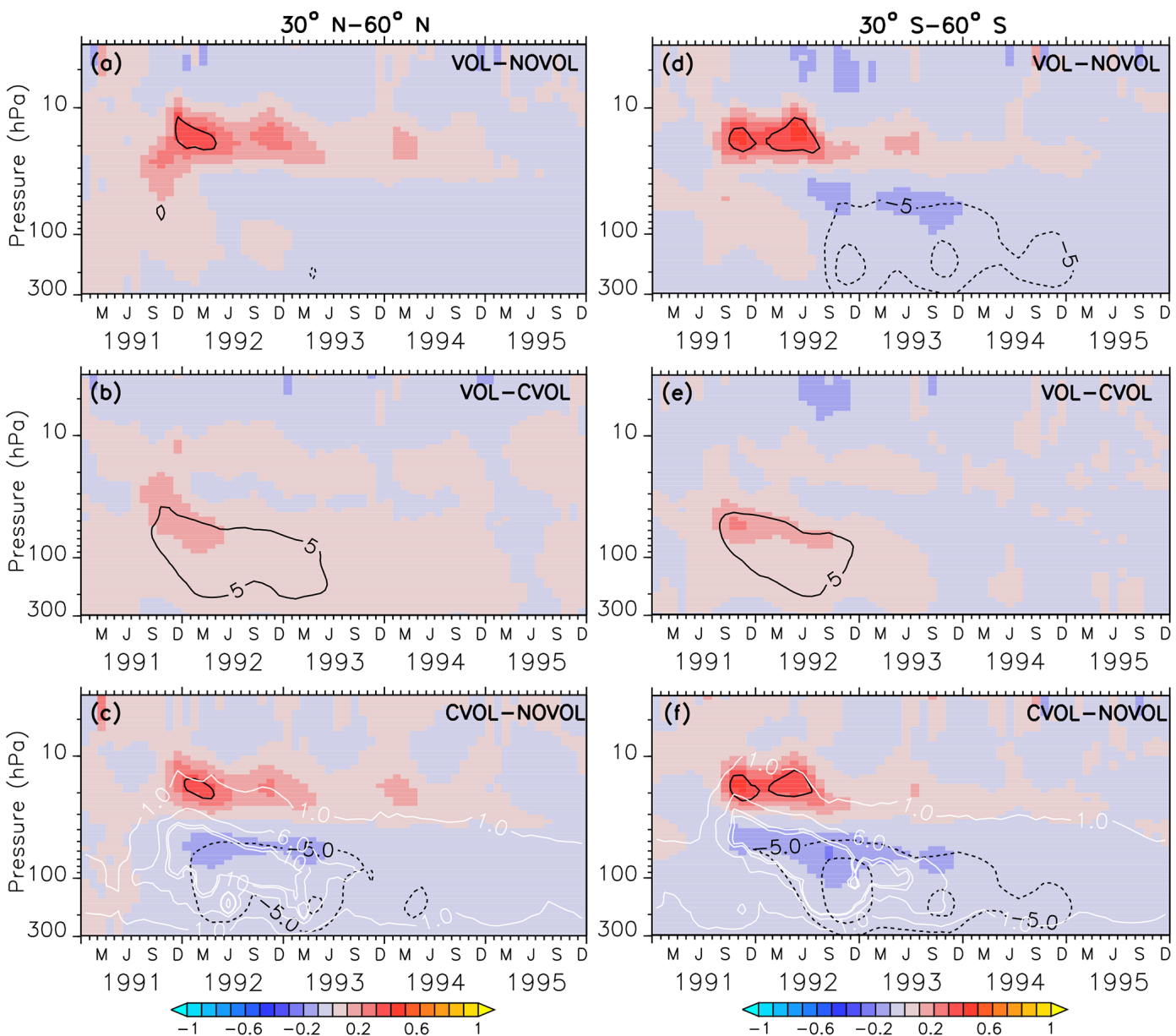

Figure 8. Zonally averaged differences in ozone mixing ratios (ppmv) between the simulations VOL-NOVOL (a, d), VOL-CVOL (b, e), and CVOL-NOVOL (c, f). Contours indicate the corresponding relative changes (\%). Shown are averages over the midlatitudes 30 $60^{\circ} \mathrm{N}(\mathbf{a}, \mathbf{b}, \mathbf{c})$ and $30-60^{\circ} \mathrm{S}(\mathbf{d}, \mathbf{e}, \mathbf{f})$. Contour intervals are $5 \%$. White contours in (c) and (f) show the liquid aerosol surface area density $\left(10^{-8} \mathrm{~cm}^{2} \mathrm{~cm}^{-3}\right)$ in VOL and CVOL with intervals of 1,5 , and 10 .

results presented show the differences between CVOL and NOVOL of the $\mathrm{O}_{3}$ production and loss rates given in molecules per second. The vertical levels shown are selected according to the largest perturbation of the $\mathrm{O}_{3}$ mixing ratio (Fig. 7). The $\mathrm{O}_{3}$ loss rates are determined by different contributions of the catalytic cycles of $\mathrm{NO}_{x}, \mathrm{ClO}_{x}, \mathrm{HO}_{x}$, $\mathrm{O}_{x}$, and $\mathrm{BrO}_{x}$.

The increase in the $\mathrm{O}_{3}$ mixing ratio in the tropics at $12 \mathrm{hPa}$ (Sect. 4.3) is explained by a strong decrease in the $\mathrm{O}_{3}$ loss rate (Fig. 10a). The $\mathrm{O}_{3}$ gain is accompanied by a reduced $\mathrm{O}_{3}$ production. The decrease in the $\mathrm{O}_{3}$ production at $12 \mathrm{hPa}$ is caused by an increase in $\mathrm{O}_{3}$, which dims the solar radiation from above and thus slows down the photolysis of oxygen (Kilian, 2018). The strong reduction in the $\mathrm{O}_{3}$ loss rate (Fig. 10a) arises from the $\mathrm{NO}_{x}$ cycle (Fig. 10b) because $\mathrm{NO}_{x}$ is transformed into the reservoir gas $\mathrm{HNO}_{3}$ due to the enhanced liquid aerosol surface. On the other hand, the $\mathrm{HO}_{x}$, $\mathrm{ClO}_{x}$, and $\mathrm{O}_{x}$ cycles accelerate and thus partly counteract the $\mathrm{NO}_{x}$ cycle slowdown towards a new chemical equilibrium.
This leads to the increase in the $\mathrm{O}_{3}$ mixing ratios at $12 \mathrm{hPa}$. The duration of the disturbed ozone loss rates (Fig. 10b) reflects the presence of the upper part of the volcanic aerosol cloud. At $30 \mathrm{hPa} \mathrm{O}_{3}$ decreases slightly because the $\mathrm{HO}_{x}$, $\mathrm{ClO}_{x}$, and $\mathrm{O}_{x}$ cycle accelerate more than the $\mathrm{NO}_{x}$ cycle decelerates (Fig. 10c).

In the midlatitudes of the Northern Hemisphere the strongest $\mathrm{O}_{3}$ increase appears at $20 \mathrm{hPa}$. Again, this is caused by a loss and production due to the volcanic aerosol, although its order of magnitude is smaller than in the tropics (Fig. 11a). However, the perturbation lasts longer. The differences in the production and loss rates in the southern midlatitudes (Fig. 11b) are half as large as in the tropics, but their duration is similar. The maxima in ozone loss rates correspond to the upper height limit of the volcanic cloud. The volcanic perturbation of the ozone budget lasts until spring 1993 in the Northern Hemisphere and until summer 1992 in the Southern Hemisphere (Fig. 11e, f). In each case, the decrease in the ozone loss rate can be attributed to a less active 

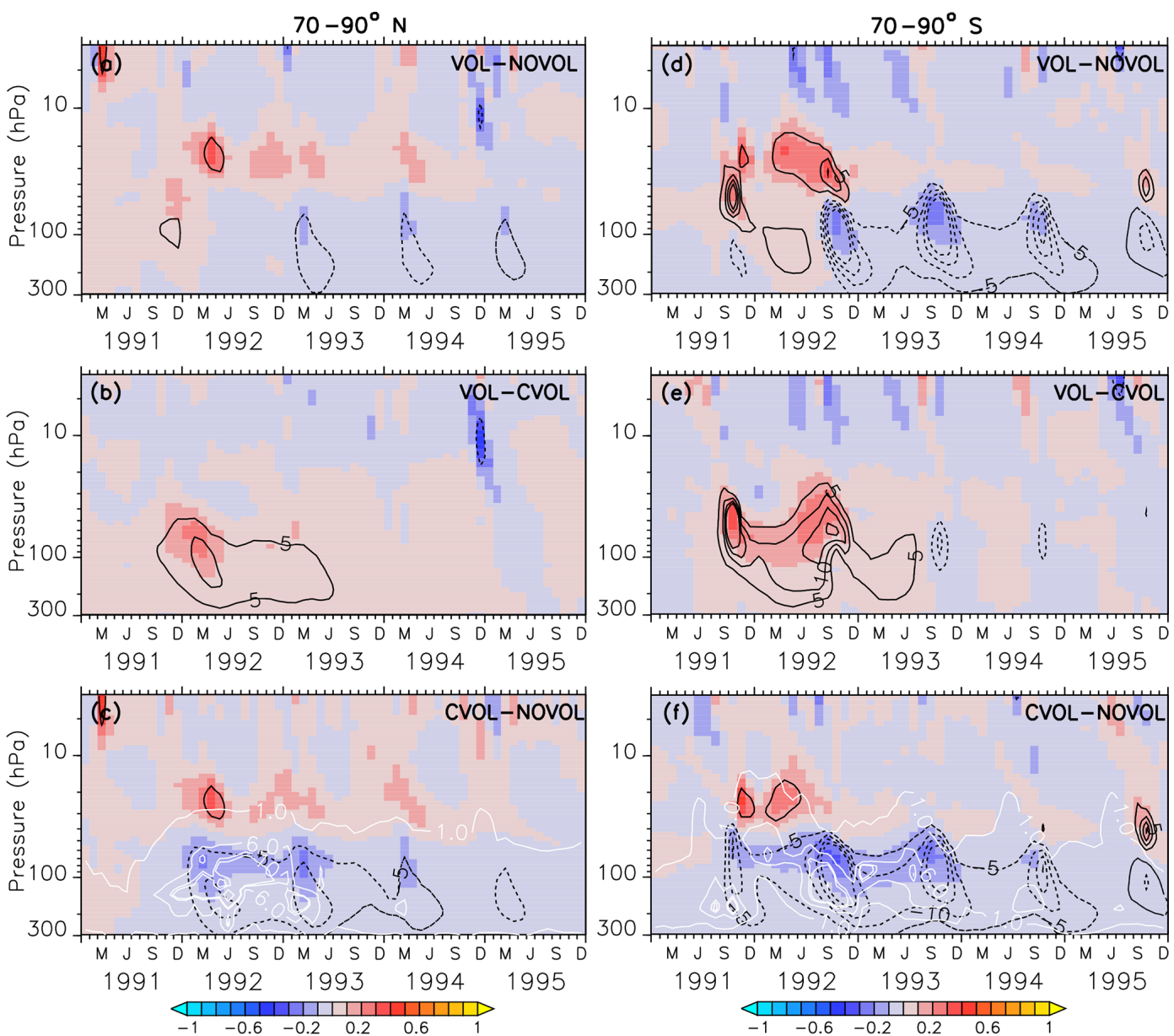

Figure 9. Zonally averaged differences in ozone mixing ratios (ppmv) between the simulations VOL-NOVOL (a, d), VOL-CVOL (b, e), and CVOL-NOVOL (c, f). Contours indicate the corresponding relative changes (\%). Shown are averages over the midlatitudes $70-$ $90^{\circ} \mathrm{N}(\mathbf{a}, \mathbf{b}, \mathbf{c})$ and $70-90^{\circ} \mathrm{S}(\mathbf{d}, \mathbf{e}, \mathbf{f})$. Contour intervals are $5 \%$. White contours in (c) and (f) show the liquid aerosol surface area density $\left(10^{-8} \mathrm{~cm}^{2} \mathrm{~cm}^{-3}\right)$ in VOL and CVOL with intervals of 1,5 , and 10 .

$\mathrm{NO}_{x}$ cycle (Fig. 11e, f) due to the conversion of reactive $\mathrm{NO}_{x}$ on the aerosol surface into $\mathrm{HNO}_{3}$. Note that at this height the $\mathrm{NO}_{x}$ cycle dominates the ozone-depleting process.

In the midlatitudes at $70 \mathrm{hPa}$ the negative differences in the net ozone production (Fig. 11g, h) arise solely from an increase in ozone loss rates and lead to the observed $\mathrm{O}_{3}$ decrease in the lower stratosphere. Moreover, a strong seasonal cycle with maximum loss rates in the respective winter is apparent. The seasonal increase in ozone loss rates is related to the predominance of the $\mathrm{ClO}_{x}$ and $\mathrm{BrO}_{x}$ cycle during the respective winter seasons. The presence of volcanic aerosols lead to a conversion of $\mathrm{NO}_{x}$ into the reservoir $\mathrm{HNO}_{3}$. Moreover, during the respective winter months with only minor sunlight, $\mathrm{NO}_{x}$ remains in the reservoir gas $\mathrm{HNO}_{3}$. The reduction of $\mathrm{NO}_{x}$ accelerates the $\mathrm{ClO}_{x}$ and $\mathrm{BrO}_{x}$ cycle in the late winter of 1992 and 1993, where the $\mathrm{ClO}_{x}$ and $\mathrm{BrO}_{x}$ cycles reach their maxima in depleting $\mathrm{O}_{3}$ (Fig. 11g, h). The increase in the ozone loss rate due to the halogens is not counterbalanced by any other cycle, which explains the strongest decrease in ozone at $70 \mathrm{hPa}$ in the late winter of 1992 and 1993 (Fig. 8b). Volcanic aerosols plus more water vapour (more $\mathrm{OH}$ ) in summer increase the importance of the $\mathrm{HO}_{x}$ cycle, which dominates the $\mathrm{O}_{3}$ removal below $20 \mathrm{~km}(50 \mathrm{hPa}$, Kilian, 2018, Fig. 4.10). Together with more $\mathrm{NO}_{x}$ removal through the volcanic cloud, the relative importance of the $\mathrm{HO}_{x}$ cycle increases.

In the polar regions the ozone loss rates at $20 \mathrm{hPa}$ also show a seasonal cycle with a strong decrease in the first respective spring season after the eruption but followed by an abrupt increase in the following summer season (Fig. 12a, b). The rapid decrease in the ozone loss rate, which is related to the first occurrence of the volcanic aerosol cloud in the north polar region in spring 1992 is 10 times smaller than in the midlatitudes (Fig. 12a, b and e, f). This abrupt change in sign is related to the beginning of solar insolation after the polar night. The strong reduction in $\mathrm{O}_{3}$ loss rates is related to the decrease in the $\mathrm{NO}_{x}$ cycle in summer, which is not compensated for by the $\mathrm{HO}_{x}$ cycle as in the midlatitudes (Fig. 12e, f). 

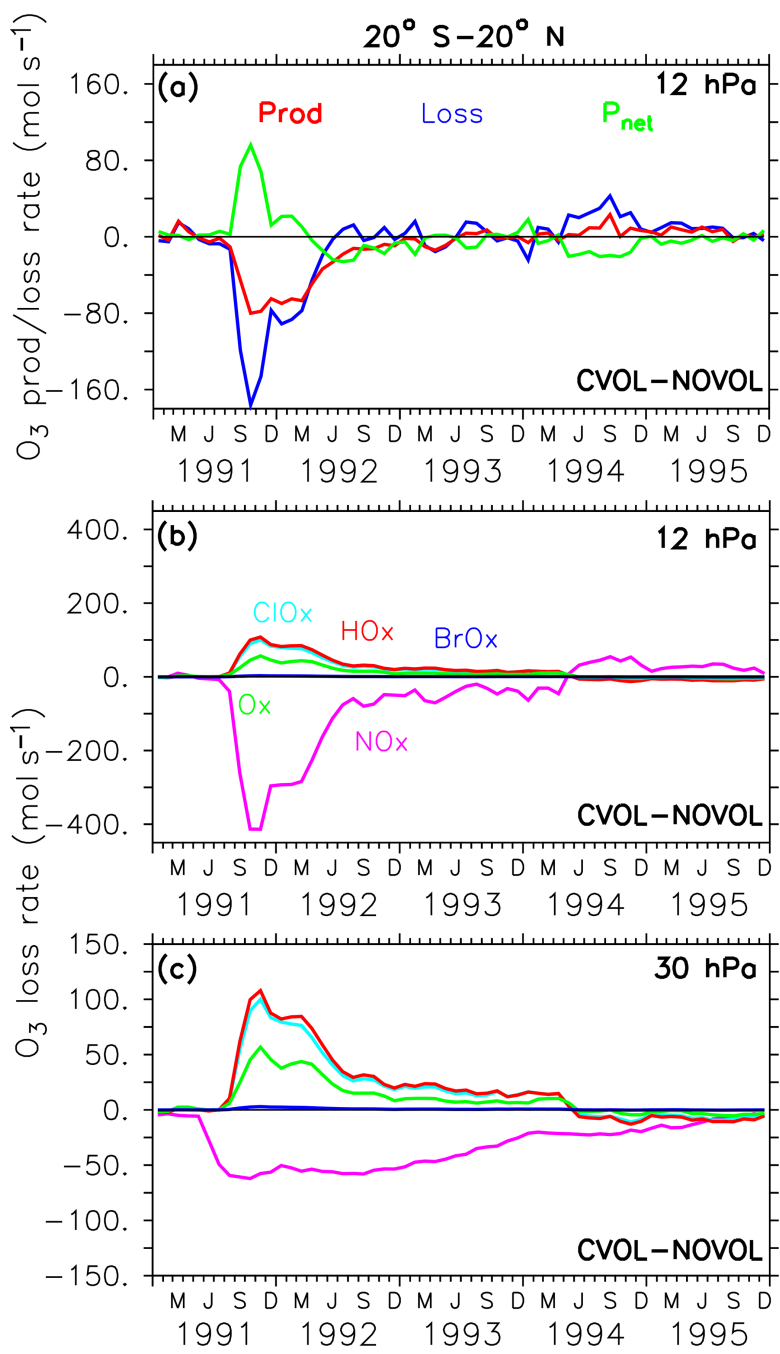

Figure 10. Differences (CVOL-NOVOL), i.e. chemical effect of ozone production (Prod) and loss (Loss) rates and corresponding net ozone production $\left(P_{\text {net }}=\right.$ Prod - Loss $)$ (a) at $12 \mathrm{hPa}$. Differences (CVOL-NOVOL) in the ozone loss rates (molecules $\mathrm{s}^{-1}$ ) for each catalytic ozone loss cycle of CVOL-NOVOL at $12 \mathrm{hPa}$ (b) and $30 \mathrm{hPa}(\mathbf{c})$. The level shown $(12 \mathrm{hPa})$ is located at the maximum of the volcanic ozone perturbation. Shown are zonally averaged and latitudinally $\left(20^{\circ} \mathrm{S}\right.$ and $\left.20^{\circ} \mathrm{N}\right)$ summed rates in molecules per second.

At $20 \mathrm{hPa}$, and only in the first spring season after the eruption and only in the south polar region, the $\mathrm{O}_{x}$ cycle becomes stronger in ozone depletion. The $\mathrm{HO}_{x}$ cycle shows a local minimum during the summer months (June and December).

The polar ozone decrease at $70 \mathrm{hPa}$ is caused by an increase in the $\mathrm{O}_{3}$ loss rate (Fig. 12c, d). Catalytic cycles have a similar seasonal variability as in the midlatitudes (Fig. 12g,h). Again, the efficiency of the $\mathrm{NO}_{x}$ cycle decreases, which is halfway compensated for by the $\mathrm{HO}_{x}$ cycle.

This can be explained by the gas-phase reaction $\mathrm{HO}_{2}+$ $\mathrm{NO} \rightarrow \mathrm{OH}+\mathrm{NO}_{2}$, which affects the interconversion between
$\mathrm{HO}_{2}$ and $\mathrm{OH}$ (Seinfeld and Pandis, 1998). Their ratio is controlled by the temperature-dependent reaction rate and by the concentrations of $\mathrm{O}_{3}$ and NO. In the lower stratosphere the reaction $\mathrm{HO}_{2}+\mathrm{O}$ is negligible, and $\mathrm{HO}_{2}+\mathrm{O}_{3}$ is predominant. Since $\mathrm{NO}_{x}$ decreases in the lower stratosphere starting in spring 1992, more $\mathrm{HO}_{2}$ is available to react with $\mathrm{O}_{3}$ instead of with NO. This leads to an increase in the relevance of the $\mathrm{HO}_{x}$ cycle for the lower stratosphere.

The acceleration of the $\mathrm{ClO}_{x}$ and $\mathrm{BrO}_{x}$ cycles in springtime starts in 1992 especially at the North Pole. Note that except for the first year after the eruption at the South Pole the $\mathrm{BrO}_{x}$ cycle is out of phase with the $\mathrm{ClO}_{x}$ cycle at $70 \mathrm{hPa}$. Probably, the deactivation of chlorine $(\mathrm{Cl})$ and bromine $(\mathrm{Br})$ atoms by a stronger polar vortex during the polar night is enhanced by the volcanic aerosol and accelerates both cycles in spring.

\section{Impact of the polar stratospheric clouds}

Next, the effects of the volcanic aerosol on the formation of PSCs are investigated. PSCs accelerate the heterogeneous chemistry because fast chemical reactions take place on the PSC particles. During the polar night the strong isolated polar vortex prevents bonded chlorine atoms from depleting ozone. PSCs appear during the polar night at heights of $25-80 \mathrm{hPa}$, which is exactly where the largest increase in the aerosol surface occurred. As soon as the first sunrays appear, $\mathrm{Cl}_{2}$ is photolysed and $\mathrm{Cl}$ atoms destruct ozone. PSCs amplify the ozone destruction because more particle surfaces are available for heterogeneous reactions. More ozone destructive reactions occur at the surface of the PSC particles to form $\mathrm{Cl}_{2}$ and $\mathrm{Br}_{2}$. The volcanic heating increases the stratospheric temperature between 30 and $70 \mathrm{hPa}$ by $3 \mathrm{~K}$ in the polar regions, implying that less PSCs form. Therefore, the heating effect (VOL-CVOL) shows less PSCs in both polar hemispheres. However, the chemical effect shows a temperature reduction in the lower stratosphere due to less ozone (Fig. 9c, f), resulting in an enhanced formation of PSCs at the North and the South Pole (Fig. 13, CVOL-NOVOL). At the North Pole, the PSC-covered area increases between November 1991 and March 1992 (Fig. 13a, CVOL-NOVOL). At the South Pole the increase in the PSC area appears in the springtime, as well as in the autumn, when the first PSCs are formed (Fig. 13b, CVOL-NOVOL). Although we cannot quantitatively differentiate between the direct effect from PSC formation and the ozone destruction, it is likely that the latter contributes to the ozone depletion in the respective spring season by enhancing the $\mathrm{ClO}_{x}$ cycle at $70 \mathrm{hPa}$.

\subsection{Stratospheric water vapour}

Similarly to Löffler et al. (2016), we find that additional water vapour is transported into the tropical stratosphere due to the heating of the tropopause by the volcanic cloud. The separation of the heating and the chemical effect shows that 

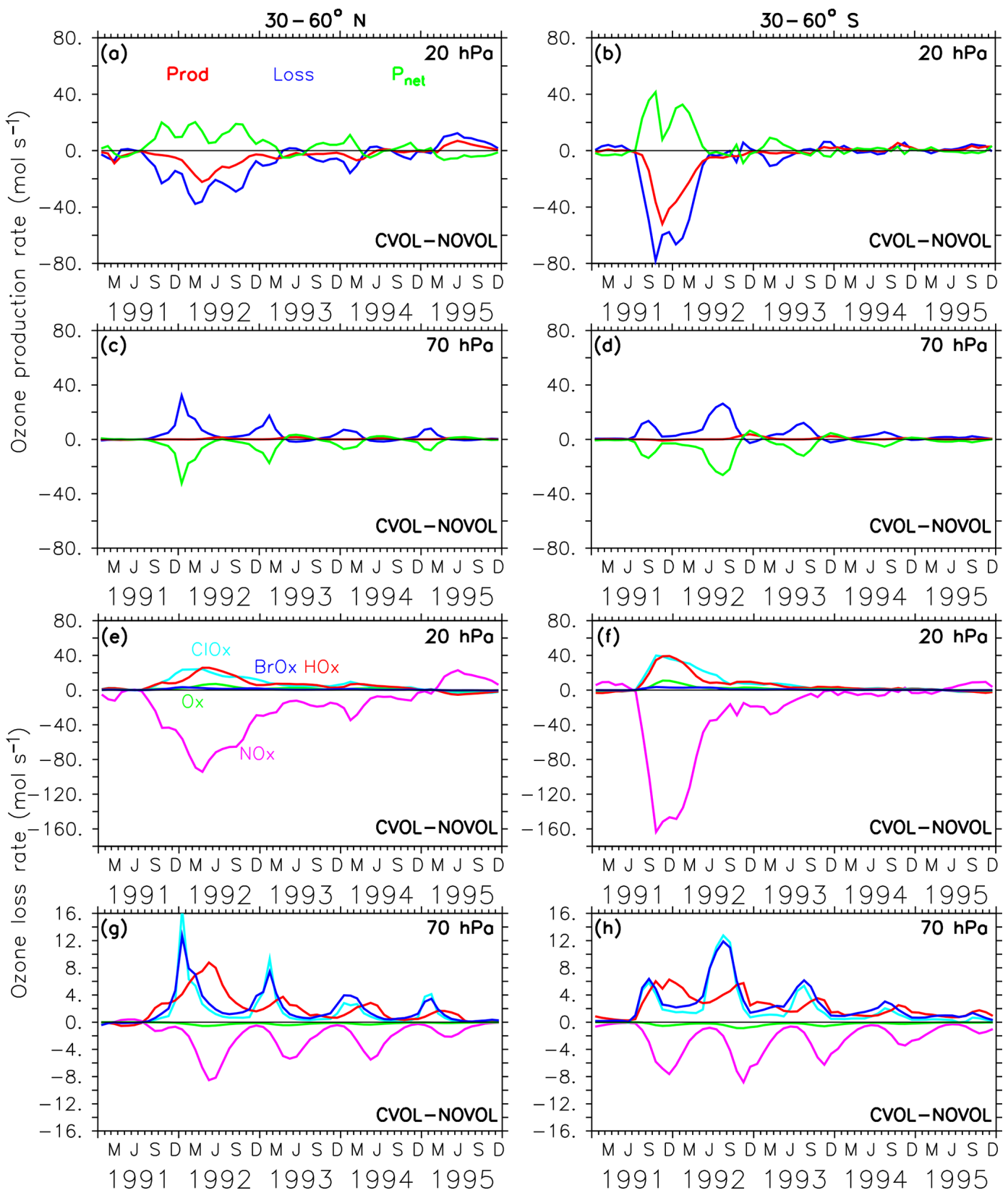

Figure 11. Chemical effect (CVOL-NOVOL) of ozone production (Prod) and loss (Loss) rates (a-d) in midlatitudes and corresponding net ozone production $\left(P_{\text {net }}=\right.$ Prod - Loss). (a) $20 \mathrm{hPa}$ and (c) $70 \mathrm{hPa}$ show zonally averaged and latitudinally $\left(30\right.$ and $\left.60^{\circ} \mathrm{N}\right)$ summed rates in molecules per second. (b, d) Similar to (a, c) but for $30-60^{\circ} \mathrm{S}$. The levels shown are located at the maximum of the volcanic ozone perturbation. Chemical effect (CVOL-NOVOL) of the zonally averaged and latitudinally summed ozone loss rates (molecules $\mathrm{s}^{-1}$ ) for each catalytic ozone loss cycle (e-h) for the Northern Hemisphere at $20 \mathrm{hPa}(\mathbf{e})$ and $70 \mathrm{hPa}(\mathbf{g})$. (f, h) are similar to (e, g) but for $30-60^{\circ} \mathrm{S}$.

only the heating effect contributes to the increase in SWV (Fig. 14a).

In the case of the chemical effect, which has not been considered by Löffler et al. (2016), the lower stratosphere is cooled by $0.4 \mathrm{~K}$ (due to less ozone), and hence less water vapour enters the stratosphere (Fig. 14b). Moreover, in September 1991 a negative SWV perturbation (outside the tape recorder) appears, following the volcanic plume
(Fig. 14b) in the first year after the eruption. This pattern is caused by sublimation of SWV into liquid and ice on the volcanic condensation nuclei.

\subsection{Methane}

Stratospheric methane $\left(\mathrm{CH}_{4}\right)$ is affected by the aerosols mainly due to the heating effect. Already 3 months after the 

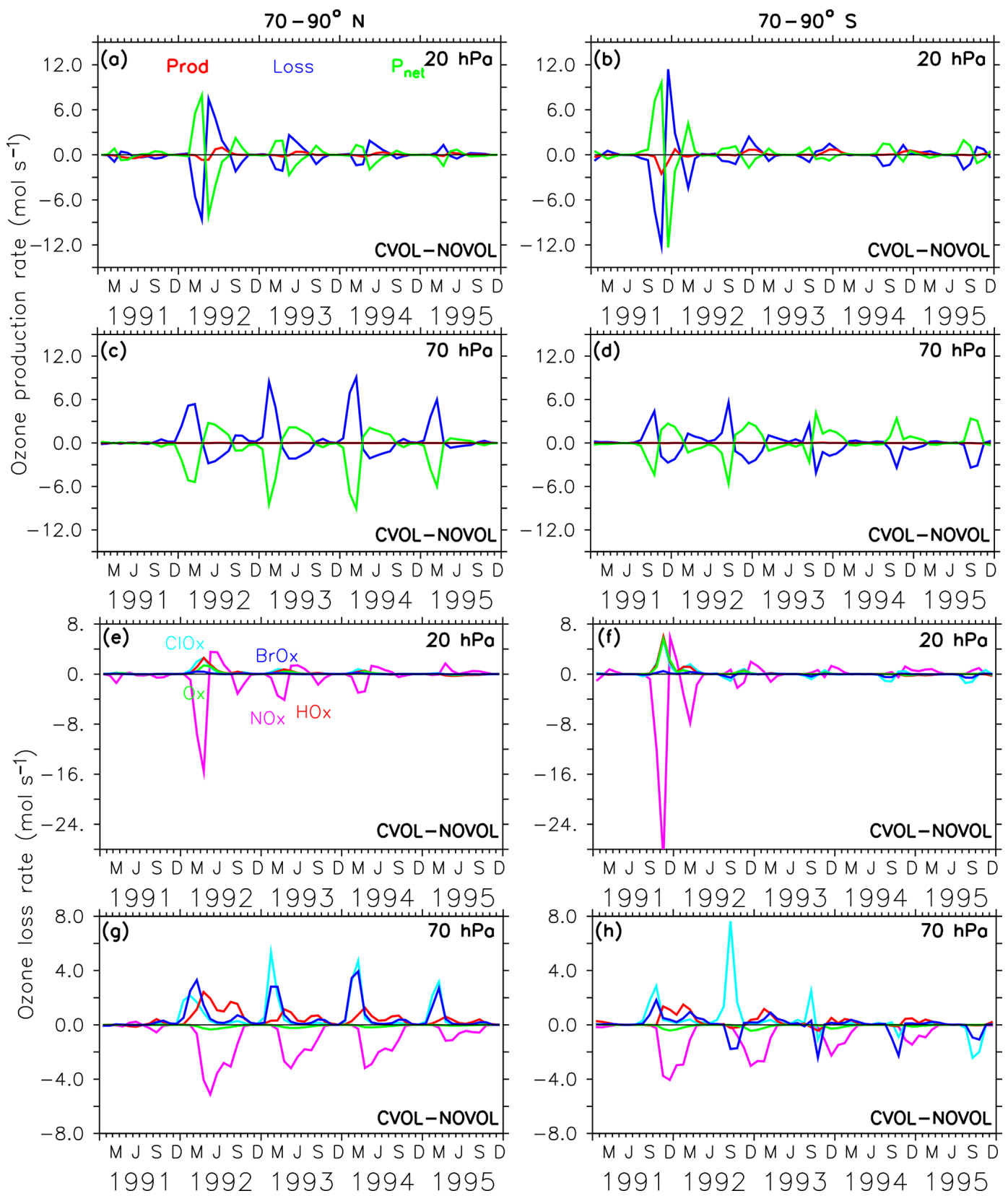

Figure 12. Chemical effect (CVOL-NOVOL) of ozone production (Prod) and loss (Loss) rates (a-d) in polar regions and corresponding net ozone production $\left(P_{\text {net }}=\right.$ Prod - Loss). (a) $20 \mathrm{hPa}$ and (c) $70 \mathrm{hPa}$ show zonally averaged and latitudinally $\left(70\right.$ and $\left.90^{\circ} \mathrm{N}\right)$ summed rates in molecules per second. (b, d) Similar to (a, c) but for $70-90^{\circ} \mathrm{S}$. The levels shown are located at the maximum of the volcanic ozone perturbation. Chemical effect (CVOL-NOVOL) of the zonally averaged and latitudinally summed ozone loss rates (molecules s ${ }^{-1}$ ) for each catalytic ozone loss cycle (e-h) for the polar region at $20 \mathrm{hPa}(\mathbf{e})$ and $70 \mathrm{hPa}(\mathbf{g})$. (f, h) are similar to (e, g) but for $70-90^{\circ} \mathrm{S}$.

eruption an increase in methane between $40 \mathrm{hPa}$ and beyond $10 \mathrm{hPa}$ can be noticed with changes in more than $80 \mathrm{ppbv}$, corresponding to a change of $10 \%$ with respect to the absolute $\mathrm{CH}_{4}$ in the unperturbed simulation NOVOL (Fig. 15a). The upward-propagating elevated values of $\mathrm{CH}_{4}$ are the result of the enhanced tropical vertical ascent, which leads to a transport from relative methane rich air in the lower stratosphere into upper levels. The surplus of $\mathrm{CH}_{4}$ is not depleted, which is an indicator that the stratospheric lifetime of $\mathrm{CH}_{4}$ has increased. In the lower stratosphere we find less $\mathrm{CH}_{4}$ due to the volcanic eruption. The dipole pattern of the $\mathrm{CH}_{4}$ perturbation spreads with time into the midlatitudes (Fig. 16a, b) and into the polar regions (Fig. 16c, d). The increase in $\mathrm{CH}_{4}$ in the tropical regions is partly transported by the deep branch of the BDC within a year to higher latitudes. But there is also a decrease in $\mathrm{CH}_{4}$ partly transported by the lower 


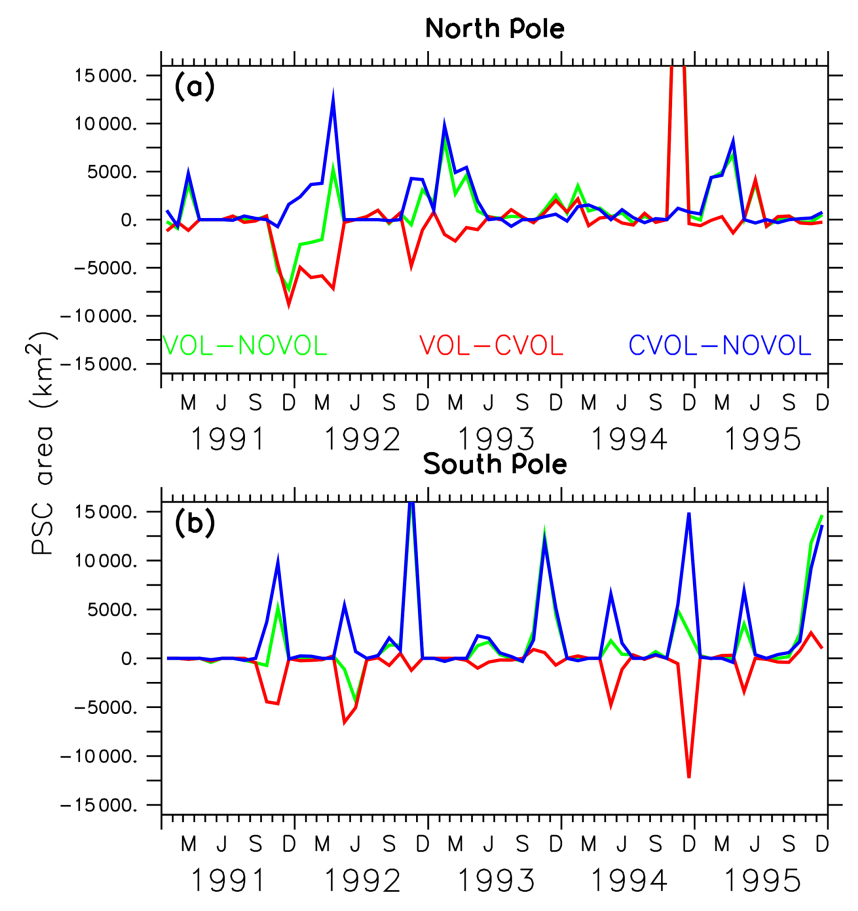

Figure 13. Differences in polar stratospheric cloud (PSC)-covered area $\left(\mathrm{km}^{2}\right)$ at the North Pole $\left(60-90^{\circ} \mathrm{N}\right)$ (a) and South Pole $(60$ $90^{\circ} \mathrm{S}$ ) (b) for the combined effect (green), the heating effect (red), and the chemical effect (blue).

branch of the BDC reaching midlatitudes within the period of 1.5-3.5 years after the eruption.

\section{Discussion}

The differences in the simulations (VOL-CVOL) separate the heating and (CVOL-NOVOL) the chemical effect. In particular, we investigated the long- and shortwave heating effect of the volcanic aerosol on the temperature and transport, as well as on ozone, $\mathrm{SWV}$, and $\mathrm{CH}_{4}$. The ozone development of the simulation VOL after the eruption is in agreement with the satellite-based SWOOSH data (Davis et al., 2016) and the TOMS data (TOMS-Science-Team, 2004). We perform specified-dynamics simulations with a prescribed aerosol distribution (CCMI data set; see Sect. 2.1). Thus, we miss the primary feedback of the aerosol-induced heating on the transport of the aerosol. But since we are interested more in the chemical effects here, this choice is advantageous because the aerosol distribution is derived from observations. The definition of a "background" aerosol distribution, relevant for the NOVOL simulation refers to a period, when volcanic activity and related aerosols are less present. Nevertheless, in the year 2011, which we selected for a background aerosol distribution, the medium-size volcanic eruption of Nabro occurred and thus is also included in the CCMI data set. In comparison with other eruptions Nabro emit-
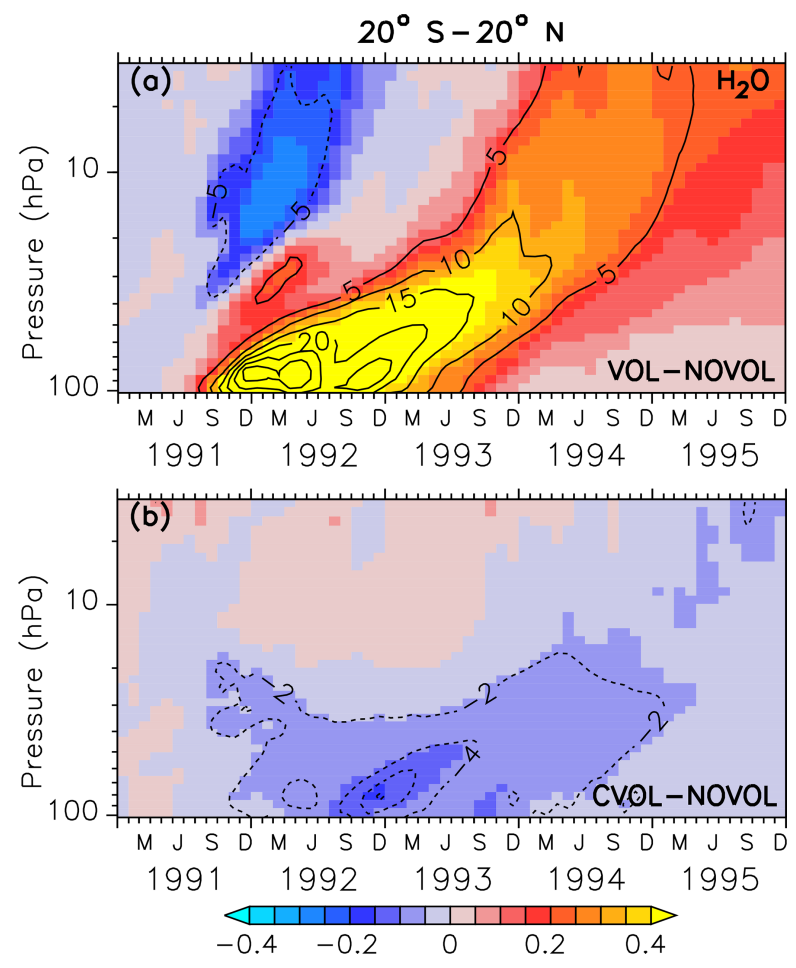

Figure 14. Zonally averaged differences in stratospheric water vapour (ppmv) between the simulations, where (a) shows the combined effect (VOL-NOVOL) and (b) the chemical effect (CVOL-NOVOL). The black contours show the relative change (\%) of water vapour in comparison to NOVOL and CVOL. Shown are tropical averages $\left(20^{\circ} \mathrm{S}-20^{\circ} \mathrm{N}\right)$. Contour intervals are $5 \%$ (a) and $2 \%$ (b).

ted only $1 \mathrm{Tg} \mathrm{SO}$ (Pinatubo: $20 \mathrm{Tg}$ ) into the atmosphere up to heights of $18 \mathrm{~km}$ (Bourassa et al., 2012). The tropopause height at $15^{\circ} \mathrm{N}$ is at $18 \mathrm{~km}$ and thus in the region of the upper part of the volcanic plume. The eruption occurred during the months of June-September 2011 (and is therefore repeated every year in the background aerosol). An important amount of aerosol is only present in the midlatitudes to high latitudes (not shown). Ozone depletion due to Mt Pinatubo might be underestimated in high latitudes (Fig. 6c) in our analysis. For the Arctic region, the ozone depletion declines systematically already in June, the month where aerosols of Nabro are present in NOVOL.

Using nudged simulations has several advantages over free-running simulations to study the impact on the chemistry: the temperature response is closer to observations, which is important, as ozone chemistry is temperature dependent. The results appear less noisy. Our nudged simulations (VOL, CVOL, and NOVOL) are similar with respect to the synoptic situation; thus the effect of aerosol heating on subgrid-scale chemistry and the transport of ozone can be emphasized more clearly. This would be more difficult if one allowed the synoptic situation to evolve freely. Moreover, for such an approach a large set of ensemble simula- 


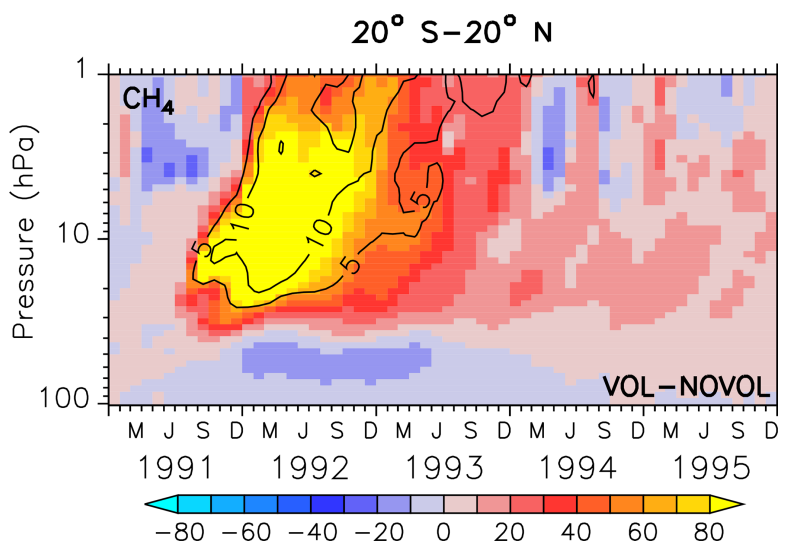

Figure 15. Zonally averaged differences in the methane mixing ratio (ppbv) for the combined effect (VOL-NOVOL). The black contours show the relative change $(\%)$ of methane in comparison to NOVOL. Shown are tropical averages $\left(20^{\circ} \mathrm{S}-20^{\circ} \mathrm{N}\right)$. Contour intervals are $5 \%$.

tions is necessary (see, for instance, Aquila et al., 2013). Another possibility is to perform simulations, in which nudging is applied up to $100 \mathrm{hPa}$, i.e. below the region where the aerosol heating occurs, together with a weak quasi-biennial oscillation (QBO) nudging, as this avoids the noisy and expensive free-running ensembles. Nudging (to ERA-interim reanalysis data) is applied to the prognostic variables temperature, divergence, and vorticity, and the logarithm of the surface pressure. We apply this nudging in the spectral space by omitting the nudging of wave zero of the temperature; thus we do not correct temperature biases, implying that the absolute temperature can evolve. Moreover, the nudging is applied as a low-normal mode insertion, i.e. down to the synoptic scale only, with comparably long relaxation times. The nudging is applied such that the large( $\mathrm{r}$ than synoptic)-scale patterns correspond to those of ERA-Interim but not the absolute temperature. This means that the synoptic situation is that of ERA-Interim, whereas sub-synoptic variations can evolve freely, as, for instance, the influence of the volcanic cloud on the vertical velocity and the temperature profile. SWV, strengthening of the vertical motion, and polar stratospheric clouds are influenced by nudging only indirectly. Because we nudge all three simulations with ERA-Interim data and prescribe SSTs and SICs, the SST part of the volcanic signal is included in all simulations and cancels out in the difference calculations. Therefore, our approach isolates the radiative and chemical effect of the volcanic aerosol on the ozone distribution.

The simulated volcanic heating of $3.5-4 \mathrm{~K}$ between 50 and $60 \mathrm{hPa}$ in VOL agrees well with results from Labitzke and McCormick (1992), who observed a stratospheric heating at $50 \mathrm{hPa}$ of $3-4.5 \mathrm{~K}$ in the tropics. Angell (1997), who used radiosonde data, figured out a temperature increase of approximately 3-4 K between 30 and $50 \mathrm{hPa}$ in late 1991 . More recent studies (Revell et al., 2017; Kuchař et al., 2017) stated that simulations using CCMI aerosol data tend to overestimate the temperature response in the stratosphere. And this in turn may affect the amount of water vapour entering the stratosphere at warmer simulated cold-point temperatures than observed. The results of Löffler et al. (2016) point in a similar direction. Their nudged simulation using CCMI aerosol data also tend to overestimate the temperature anomaly after the Mt Pinatubo eruption. Grant et al. (1992), Schoeberl et al. (1993), and Angell (1997) investigated total ozone column depletions of $5 \%-8 \%$ in the tropical region 6 months after the Mt Pinatubo eruption. Our findings with up to $6 \%$ column loss agree quite well with these results and with measurements from the Mauna Loa observatory on Hawaii, showing a $5 \% \mathrm{O}_{3}$ column loss (Randel et al., 1995). McCormick et al. (1995) indicated the same order of magnitude from observation data with an ozone loss of $6 \%-8 \%$ over the Equator in the first several months after eruption. Grant et al. (1992) reported the absolute change in the ozone column in the tropics to be 13-20 DU, which is in agreement with our study with decreases in 10-18 DU. Grant et al. (1992) and McCormick et al. (1995) observed the largest tropical loss of ozone with $20 \%$ between 24 and $25 \mathrm{~km}(25-30 \mathrm{hPa}$ level), which is $5 \%$ more than the perturbation in our study. Although the ozone production rates slow down (due to the local increase in ozone abundance), they might still be too high because the simulated photolysis rates do not account for the presence of the volcanic aerosol. The ozone change after a volcanic eruption is a combination of an ozone decrease in the vertical column in the tropics directly after the eruption and an ozone increase in the midlatitudes and polar regions in the first year after the eruption. Poberaj et al. (2011) reported a similar temporal behaviour of the ozone decrease after the Mt Pinatubo eruption. They quantified an ozone decrease of $3 \%-4 \%$ in the southern midlatitudes. Telford et al. (2009) reported a total ozone reduction of $10 \mathrm{DU}$ averaged between 30 and $60^{\circ} \mathrm{N}$ and $12 \mathrm{DU}$ between 30 and $60^{\circ} \mathrm{S}$ caused by the chemical effect. In general, the chemical effect on ozone perturbation becomes more important at higher latitudes (Telford et al., 2009). Our results show that the ozone increase in the extratropics in the year after the eruption can be solely attributed to the heating effect, i.e. the effect of increased transport of ozone with the BDC. Joshi and Shine (2003) simulated water vapour increases of $20 \%-30 \%$ in the tropics between $10^{\circ} \mathrm{S}$ and $10^{\circ} \mathrm{N}$ after the Mt Pinatubo eruption. Considine et al. (2001) simulated SWV and $\mathrm{CH}_{4}$ anomalies between 0 and $10^{\circ} \mathrm{N}$ and showed increases in the vertical ascent in the tropical lower stratosphere of up to $24 \%$. Referring to their Fig. 16b, they stated a positive SWV anomaly of $15 \%-20 \%$ starting in October 1991 following the tape recorder signal. Our study confirms these results quantitatively and in terms of spatial and quantitative distribution. Furthermore, Considine et al. (2001) found increased values of $\mathrm{CH}_{4}$ with $2 \%$ at $10 \mathrm{hPa}$, which reached amplitudes of up to $10 \%$ at $0.1 \mathrm{hPa}$. In our simulation, the largest rel- 

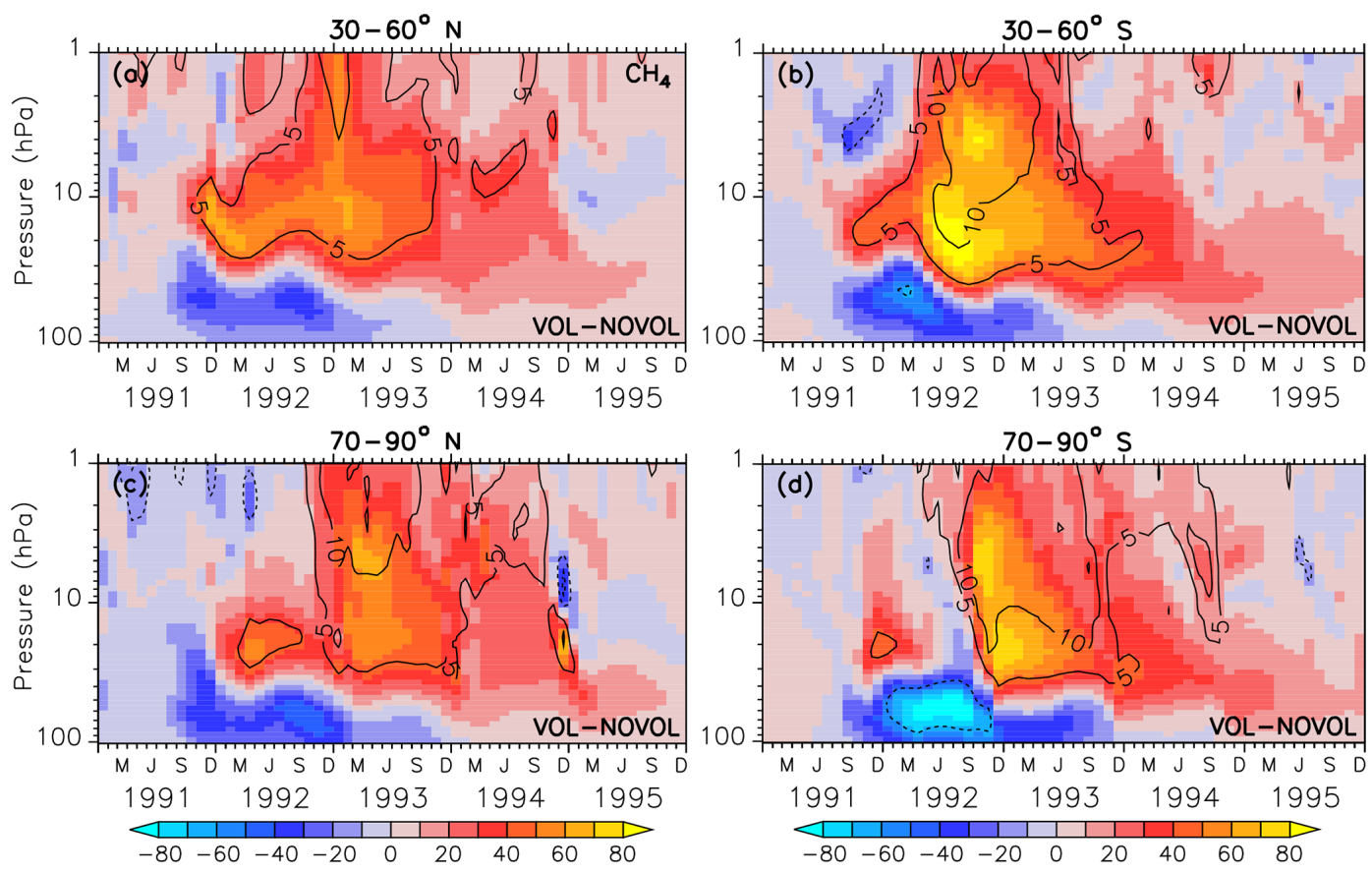

Figure 16. Zonally averaged differences in methane (ppbv) of the combined effect (VOL-NOVOL). The black contours show the relative change (\%) in methane in VOL comparison to NOVOL. Shown are extratropical averages (a, b: $30-60^{\circ} \mathrm{N}$ and $30-60^{\circ} \mathrm{S} ; \mathbf{c}, \mathbf{d}$ : $70-90^{\circ} \mathrm{N}$ and $70-90^{\circ} \mathrm{S}$ ). Contour intervals are $5 \%$.

ative methane anomalies caused by volcanic heating occur between $20 \mathrm{hPa}$ and up to $1 \mathrm{hPa}$. Probably, this methane increase is predominantly caused by the stronger vertical ascent and less by secondary chemical effects. In the heating effect, we cannot explicitly differentiate between a stronger vertical transport and a smaller-extent temperature influence on the chemistry. Winterstein et al. (2019) showed that the concentration of $\mathrm{OH}$, which determines the lifetime of $\mathrm{CH}_{4}$, is dependent on SWV and $\mathrm{O}_{3}$. This leads us to the limitation of our study, namely that the perturbation of the chemical composition arises from a temperature-induced enhancement of the transport and of the temperature-dependent heterogeneous reaction rates (secondary effect). Both effects are included in the heating effect (VOL-CVOL) but cannot be separated in this study.

\section{Summary}

We presented an analysis with the focus on the changes in ozone, methane, and water vapour, caused by the volcanic aerosols of the Mt Pinatubo eruption in 1991 as simulated with the chemistry-climate model EMAC. We performed three specified-dynamics simulations with prescribed volcanic aerosol, which differ with respect to the interaction between volcanic aerosol, chemistry, and radiation: VOL (volcanic aerosol: interaction with radiation and heterogeneous chemistry), NOVOL (no volcanic aerosol), and CVOL (volcanic aerosol: interaction with chemistry, no interaction with radiation). This enables the separation of the effect of volcanic heating on the atmospheric composition from the chemical effect, i.e. the effect of heterogeneous reaction rates on volcanic aerosols on the ozone distribution.

Although we use specified-dynamics simulations, the effect of volcanic heating on the BDC is visible in an increase in vertical velocity, especially in the tropics, with subsequent increased horizontal transport of heat and tracers with the BDC.

Further, the use of specified-dynamics simulations allows us to eliminate the effect of the large-scale meteorology (e.g. QBO, ENSO) when the simulations are compared. This is important, as, for instance, the eruption of Mt Pinatubo coincided with a time period of strong upwelling in the tropics with related cooling. As a result, the observed tropopause temperatures were lower than expected through the eruption. This might also be the reason why free-running models have a tendency to overestimate the temperature response in the stratosphere. This is the fundamental difference to other studies on the effect of the Mt Pinatubo eruption on the ozone distribution, such as Aquila et al. (2013) and Muthers et al. (2015). Amongst other things, they studied the contribution of interannual dynamical variability to the ozone distribution after the eruption.

The major finding in our study is that the chemical effect shows up globally as a dipole structure in the vertical ozone distribution with an ozone increase around $10-30 \mathrm{hPa}$ and a decrease below down to the tropopause. These two verti- 
cal regions are characterized by a different importance of the $\mathrm{NO}_{x}$ cycle.

The dominant chemical increase in ozone (1 year after the eruption around $10-30 \mathrm{hPa}$ ) is caused by a reduction of $\mathrm{NO}_{x}$ into $\mathrm{HNO}_{3}$ on the volcanic aerosol, i.e. a slowdown in the ozone-depleting $\mathrm{NO}_{x}$ cycle.

The ozone decrease (in the lower stratosphere in midlatitudes to high latitudes), however, is caused by an acceleration of the ozone-depleting cycles $\mathrm{ClO}_{x}, \mathrm{BrO}_{x}$, and $\mathrm{HO}_{x}$ as a result of the reduced $\mathrm{NO}_{x}$ cycle. Moreover, these chemical cycles show a strong seasonal variability in midlatitudes and high latitudes. SWV and $\mathrm{CH}_{4}$ were increased by the heating effect by up to $25 \%$ and $10 \%$ in the tropics, respectively, and in contrast to $\mathrm{O}_{3}$, for $\mathrm{SWV}$ and $\mathrm{CH}_{4}$ the chemical effect has less importance.

Code and data availability. The simulation results and the computer code used here are archived at the German Climate Computing Center (DKRZ) and are available on request.

Author contributions. MK analysed the data and wrote the paper. $\mathrm{SB}$ and PJ designed the experiments, performed the model simulations, and contributed to the paper.

Competing interests. The authors declare that they have no conflict of interest.

Special issue statement. This article is part of the special issue "The Modular Earth Submodel System (MESSy) (ACP/GMD interjournal SI)". It is not associated with a conference.

Acknowledgements. This study was funded by the DLR project KliSAW. We acknowledge the use of the tool cdo (https://code.mpimet. mpg.de/projects/cdo, last access: 7 October 2020) for the processing of data and the program Ferret from NOAA's Pacific Marine Environmental Laboratory (https://ferret.pmel.noaa.gov/Ferret/, last access: 7 October 2020) for analysis and creation of graphics in this study. We thank Davis et al. (2016) for providing the SWOOSH data. We gratefully acknowledge the support of NASA/GSFC's Ozone Processing Team in providing the TOMS data presented here. The SBUV/2 data were obtained from NOAA/NESDIS with support from the NOAA Climate and Global Change Atmospheric Chemistry Element (Wellemeyer et al., 2004). We further thank the German Climate Computing Centre (DKRZ) for providing computational resources for the simulations and for data processing and analysis. We thank Heidi Huntrieser and Volker Grewe for the internal review of our paper.

Financial support. The article processing charges for this openaccess publication were covered by a Research Centre of the Helmholtz Association.
Review statement. This paper was edited by Farahnaz Khosrawi and reviewed by two anonymous referees.

\section{References}

Angell, J.: Estimated Impact of Agung, El Chichon, and Pinatubo Volcanic Eruptions on Global and Regional total ozone after Adjustment for the QBO, Geophys. Res. Lett., 24, 647-650, 1997.

Aquila, V., Oman, L. D., Stolarski, R., Douglass, A. R., and Newman, P. A.: The Response of Ozone and Nitrogen Dioxide to the Eruption of Mt. Pinatubo at Southern and Northern Midlatitudes, J. Atmos. Sci., 70, 894-900, https://doi.org/10.1175/JAS-D-120143.1, 2013.

Bourassa, A., Robock, A., Randel, W., Deshler, T., Rieger, L., Lloyd, N., Llewellyn, E., and Degenstein, D.: Large Volcanic Aerosol Load in the Stratosphere Linked to Asian Monsoon Transport, Science, 337, 78-81, https://doi.org/10.1126/science.1219371, 2012.

Brühl, C., Lelieveld, J., Tost, H., Häpfner, M., and Glatthor, N.: Stratospheric sulfur and its implications for radiative forcing simulated by the chemistry climate model EMAC, J. Geophys. Res.-Atmos., 120, 2103-2118, https://doi.org/10.1002/2014JD022430, 2015.

Considine, D. B., Rosenfield, J. E., and Fleming, E. L.: An interactive model study of the influence of the Mount Pinatubo aerosol on stratospheric methane and water trends, J. Geophys. Res., 106, 27711-27727, https://doi.org/10.1029/2001JD000331, 2001.

Dameris, M., Grewe, V., Ponater, M., Deckert, R., Eyring, V., Mager, F., Matthes, S., Schnadt, C., Stenke, A., Steil, B., Brühl, C., and Giorgetta, M. A.: Long-term changes and variability in a transient simulation with a chemistry-climate model employing realistic forcing, Atmos. Chem. Phys., 5, 2121-2145, https://doi.org/10.5194/acp-5-2121-2005, 2005.

Davis, S. M., Rosenlof, K. H., Hassler, B., Hurst, D. F., Read, W. G., Vömel, H., Selkirk, H., Fujiwara, M., and Damadeo, R.: The Stratospheric Water and Ozone Satellite Homogenized (SWOOSH) database: a long-term database for climate studies, Earth Syst. Sci. Data, 8, 461-490, https://doi.org/10.5194/essd8-461-2016, 2016.

Dee, D. P., Uppala, S. M., Simmons, A. J., Berrisford, P., Poli, P., Kobayashi, S., Andrae, U., Balmaseda, M. A., Balsamo, G., Bauer, P., Bechtold, P., Beljaars, A. C. M., van de Berg, L., Bidlot, J., Bormann, N., Delsol, C., Dragani, R., Fuentes, M., Geer, A. J., Haimberger, L., Healy, S. B., Hersbach, H., Hólm, E. V., Isaksen, L., Kållberg, P., Köhler, M., Matricardi, M., McNally, A. P., Monge-Sanz, B. M., Morcrette, J.-J., Park, B.-K., Peubey, C., de Rosnay, P., Tavolato, C., Thépaut, J.-N., and Vitart, F.: The ERA-Interim reanalysis: configuration and performance of the data assimilation system, Q. J. Roy. Meteor. Soc., 137, 553-597, https://doi.org/10.1002/qj.828, 2011.

Diallo, M., Ploeger, F., Konopka, P., Birner, T., Müller, R., Riese, M., Garny, H., Legras, B., Ray, E., Berthet, G., and Jegou, F.: Significant Contributions of Volcanic Aerosols to Decadal Changes in the Stratospheric Circulation, Geophys. Res. Lett., 44, 1078010791, https://doi.org/10.1002/2017GL074662, 2017.

Grant, W. B., Fishman, J., Browell, E. V., Brackett, V. G., Nganga, D., Minga, A., Cros, B., Veiga, R. E., Butler, C. F., Fenn, M. A., and Nowicki, G. D.: Observations of reduced 
ozone concentrations in the tropical stratosphere after the eruption of Mt. Pinatubo, Geophys. Res. Lett., 19, 1109-1112, https://doi.org/10.1029/92GL01153, 1992.

Grewe, V., Tsati, E., Mertens, M., Frömming, C., and Jöckel, P.: Contribution of emissions to concentrations: the TAGGING 1.0 submodel based on the Modular Earth Submodel System (MESSy 2.52), Geosci. Model Dev., 10, 2615-2633, https://doi.org/10.5194/gmd-10-2615-2017, 2017.

Griessbach, S., Hoffmann, L., Spang, R., von Hobe, M., Müller, R., and Riese, M.: Infrared limb emission measurements of aerosol in the troposphere and stratosphere, Atmos. Meas. Tech., 9, 4399-4423, https://doi.org/10.5194/amt-9-4399-2016, 2016.

Jöckel, P., Tost, H., Pozzer, A., Brühl, C., Buchholz, J., Ganzeveld, L., Hoor, P., Kerkweg, A., Lawrence, M. G., Sander, R., Steil, B., Stiller, G., Tanarhte, M., Taraborrelli, D., van Aardenne, J., and Lelieveld, J.: The atmospheric chemistry general circulation model ECHAM5/MESSy1: consistent simulation of ozone from the surface to the mesosphere, Atmos. Chem. Phys., 6, 50675104, https://doi.org/10.5194/acp-6-5067-2006, 2006.

Jöckel, P., Kerkweg, A., Pozzer, A., Sander, R., Tost, H., Riede, H., Baumgaertner, A., Gromov, S., and Kern, B.: Development cycle 2 of the Modular Earth Submodel System (MESSy2), Geosci. Model Dev., 3, 717-752, https://doi.org/10.5194/gmd-3717-2010, 2010.

Jöckel, P., Tost, H., Pozzer, A., Kunze, M., Kirner, O., Brenninkmeijer, C. A. M., Brinkop, S., Cai, D. S., Dyroff, C., Eckstein, J., Frank, F., Garny, H., Gottschaldt, K.-D., Graf, P., Grewe, V., Kerkweg, A., Kern, B., Matthes, S., Mertens, M., Meul, S., Neumaier, M., Nützel, M., Oberländer-Hayn, S., Ruhnke, R., Runde, T., Sander, R., Scharffe, D., and Zahn, A.: Earth System Chemistry integrated Modelling (ESCiMo) with the Modular Earth Submodel System (MESSy) version 2.51, Geosci. Model Dev., 9, 1153-1200, https://doi.org/10.5194/gmd-9-1153-2016, 2016.

Joshi, M. and Shine, K.: A GCM Study of Volcanic Eruptions as a Cause of Increased Stratospheric Water Vapor, J. Climate, 16, https://doi.org/10.1175/15200442(2003)016<3525:AGSOVE>2.0.CO;2, 2003.

Khosrawi, F., Kirner, O., Sinnhuber, B.-M., Johansson, S., Höpfner, M., Santee, M. L., Froidevaux, L., Ungermann, J., Ruhnke, R., Woiwode, W., Oelhaf, H., and Braesicke, P.: Denitrification, dehydration and ozone loss during the 2015/2016 Arctic winter, Atmos. Chem. Phys., 17, 1289312910, https://doi.org/10.5194/acp-17-12893-2017, 2017.

Khosrawi, F., Kirner, O., Stiller, G., Höpfner, M., Santee, M. L., Kellmann, S., and Braesicke, P.: Comparison of ECHAM5/MESSy Atmospheric Chemistry (EMAC) simulations of the Arctic winter 2009/2010 and 2010/2011 with Envisat/MIPAS and Aura/MLS observations, Atmos. Chem. Phys., 18, 8873-8892, https://doi.org/10.5194/acp-18-88732018, 2018.

Kilian, M.: Impact of the eruption of Mt. Pinatubo on the chemical composition of the tropical atmosphere as simulated with EMAC, Master thesis, University of Innsbruck (LFU), Austria, available at: http://diglib.uibk.ac.at/ulbtirolhs/content/titleinfo/ 2601841 (last access: 7 October 2020), 2018.

Kuchař, A., Ball, W. T., Rozanov, E. V., Stenke, A., Revell, L., Miksovsky, J., Pisoft, P., and Peter, T.: On the aliasing of the solar cycle in the lower stratospheric tropi- cal temperature, J. Geophys. Res.-Atmos., 122, 9076-9093, https://doi.org/10.1002/2017JD026948, 2017.

Labitzke, K. and McCormick, M. P.: Stratospheric temperature increases due to Pinatubo aerosols, Geophys. Res. Lett., 19, 207210, https://doi.org/10.1029/91GL02940, 1992.

Löffler, M., Brinkop, S., and Jöckel, P.: Impact of major volcanic eruptions on stratospheric water vapour, Atmos. Chem. Phys., 16, 6547-6562, https://doi.org/10.5194/acp-166547-2016, 2016.

McCormick, M. P., Thomason, L. W., and Trepte, C. R.: Atmospheric effects of the Mt Pinatubo eruption, Nature, 373, 399404, https://doi.org/10.1038/373399a0, 1995.

Meul, S., Langematz, U., Oberländer, S., Garny, H., and Jöckel, P.: Chemical contribution to future tropical ozone change in the lower stratosphere, Atmos. Chem. Phys., 14, 2959-2971, https://doi.org/10.5194/acp-14-2959-2014, 2014.

Muthers, S., Arfeuille, F., Raible, C. C., and Rozanov, E.: The impacts of volcanic aerosol on stratospheric ozone and the Northern Hemisphere polar vortex: separating radiative-dynamical changes from direct effects due to enhanced aerosol heterogeneous chemistry, Atmos. Chem. Phys., 15, 11461-11476, https://doi.org/10.5194/acp-15-11461-2015, 2015.

Poberaj, C. S., Staehelin, J., and Brunner, D.: Missing Stratospheric Ozone Decrease at Southern Hemisphere Middle Latitudes after Mt. Pinatubo: A Dynamical Perspective, J. Atmos. Sci., 68, 1922-1945, https://doi.org/10.1175/JAS-D-10-05004.1, 2011.

Randel, W. J., Wu, F., Russell III, J. M., Waters, J. W., and Froidevaux, L.: Ozone and temperature changes in the stratosphere following the eruption of Mount Pinatubo, J. Geophys. Res., 100, 16753-16764, https://doi.org/10.1029/95JD01001, 1995.

Revell, L. E., Stenke, A., Luo, B., Kremser, S., Rozanov, E., Sukhodolov, T., and Peter, T.: Impacts of Mt Pinatubo volcanic aerosol on the tropical stratosphere in chemistryclimate model simulations using CCMI and CMIP6 stratospheric aerosol data, Atmos. Chem. Phys., 17, 13139-13150, https://doi.org/10.5194/acp-17-13139-2017, 2017.

Robock, A.: Volcanic eruptions and climate, Rev. Geophys., 38, 191-219, https://doi.org/10.1029/1998RG000054, 2000.

Roeckner, E., Brokopf, R., Esch, M., Giorgetta, M., Hagemann, S., Kornblueh, L., Manzini, E., Schlese, U., and Schulzweida, U.: Sensitivity of Simulated Climate to Horizontal and Vertical Resolution in the ECHAM5 Atmosphere Model, J. Climate, 19, 3771-3791, https://doi.org/10.1175/JCLI3824.1, 2006.

Rozanov, V., Buchwitz, M., Eichmann, K.-U., de Beek, R., and Burrows, J.: Sciatran - a new radiative transfer model for geophysical applications in the 240-2400 NM spectral region: the pseudo-spherical version, Adv. Space Res., 29, 1831-1835, https://doi.org/10.1016/S0273-1177(02)00095-9, 2002.

Schoeberl, M., Bhartia, P., Hilsenrath, E., and Torres, O.: Tropical ozone loss following the eruption of Mt. Pinatubo, Geophys. Res. Lett., 20, https://doi.org/10.1029/92GL02637, 1993.

Seinfeld, J. and Pandis, S.: Atmospheric chemistry and physics: from air pollution to climate change, A Wiley interscience publication, Wiley, available at: https://books.google.de/books?id= IK8PAQAAMAAJ (last access: 7 October 2020), 1998.

Self, S., Zhao, J.-X., Holasck, R. E., Torres, R. C., and King, A. J.: The atmospheric impact of the 1991 Mount Pinatubo eruption, in: Fire and Mud: Eurptions and Lahars of Mount Pinatubo, Philippines, edited by: Newhall, C. G. and Punongbayan, R. S., 
Philippine Institute of Volcanology and Seismology, Queen Citv, and University of Washington Press, Seattle, 1089-1115, 1996.

Solomon, S.: Stratospheric ozone depletion: A review of concepts and history, Rev. Geophys., 37, 275-316, https://doi.org/10.1029/1999RG900008, 1999.

Solomon, S., Portmann, R. W., Garcia, R. R., Thomason, L. W., Poole, L. R., and McCormick, M. P.: The role of aerosol variations in anthropogenic ozone depletion at northern midlatitudes, J. Geophys. Res., 101, 6713-6727, https://doi.org/10.1029/95JD03353, 1996.

Stenchikov, G. L., Kirchner, I., Robock, A., Graf, H.-F., Antuña, J. C., Grainger, R. G., Lambert, A., and Thomason, L.: Radiative forcing from the 1991 Mount Pinatubo volcanic eruption, J. Geophys. Res., 103, 13837-13857, https://doi.org/10.1029/98JD00693, 1998.

Telford, P., Braesicke, P., Morgenstern, O., and Pyle, J.: Reassessment of causes of ozone column variability following the eruption of Mount Pinatubo using a nudged CCM, Atmos. Chem. Phys., 9, 4251-4260, https://doi.org/10.5194/acp-9-4251-2009, 2009b.

Textor, C., Graf, H.-F., Timmreck, C., and Robock, A.: Emissions from volcanoes, in: Emissions of Atmospheric Trace Compounds, edited by: Granier, C., Artaxo, P., and Reeves, C. E., Springer Netherlands, Dordrecht, 18, 269-303, https://doi.org/10.1007/978-1-4020-2167-1_7, 2004.
Thomas, M. A., Giorgetta, M. A., Timmreck, C., Graf, H.-F., and Stenchikov, G.: Simulation of the climate impact of Mt. Pinatubo eruption using ECHAM5 - Part 2: Sensitivity to the phase of the QBO and ENSO, Atmos. Chem. Phys., 9, 3001-3009, https://doi.org/10.5194/acp-9-3001-2009, 2009.

TOMS-Science-Team: TOMS Earth-Probe Total Ozone (O3) Aerosol Index UV-Reflectivity UV-B Erythemal Irradiance Daily L3 Global 1 deg x 1.25 deg V008, Goddard Earth Sciences Data and Information Services Center (GES DISC), Greenbelt, MD, 2004.

von Glasow, R., Bobrowski, N., and Kern, C.: The effects of volcanic eruptions on atmospheric chemistry, Chem. Geol., 263 131-142, https://doi.org/10.1016/j.chemgeo.2008.08.020, 2009.

Wellemeyer, C. G., Bhartia, P. K., McPeters, R. D., Taylor, S. L., and Ahn, Ch.: A new release of data from the Total Ozone Mapping Spectrometer (TOMS), available at: http: //www.sparc-climate.org/fileadmin/customer/6_Publications/ Newsletter_PDF/22_SPARCnewsletter_Jan2004.pdf (last access: 14 October 2020), SPARC Newsletter, 22, 37-38, 2004.

Winterstein, F., Tanalski, F., Jöckel, P., Dameris, M., and Ponater, M.: Implication of strongly increased atmospheric methane concentrations for chemistry-climate connections, Atmos. Chem. Phys., 19, 7151-7163, https://doi.org/10.5194/acp19-7151-2019, 2019.

WMO: WMO Statement on the state of the global climate in 2018, WMO-No. 1233, 44 pp., 2019. 